ARChIWA - Kancelarie - ZBIORY

NR $4(6) / 2013$

Monika CoŁbecka

Toruń

\title{
BADANIE SYSTEMU INFORMACJI ARCHIWALNEJ na Przykładzie Archiwum Państwowego W TORUnIU
}

Słowa kluczowe: metody badawcze archiwistyki, metoda reprezentacyjna, eksperyment, metody matematyczne, system informacji archiwalnej, wskaźniki efektywności informacyjnej, analiza systemowa, Archiwum Państwowe w Toruniu

Key words: the archive studies research methods; survey sampling method; experiment; mathematical method; archival information system; information effectiveness ratios; system analysis; the State Archive in Toruń

Abstract

Celem tego tekstu jest ukazanie, jak można przeprowadzić badanie systemu informacji archiwalnej (systemu wyszukiwawczego oraz systemu udostępniania) za pomocą metod matematycznych. Badanie polegało na wybraniu dla danego archiwum reprezentacyjnej liczby zespołów, a w nich jednostek archiwalnych, zebraniu (bez pośrednictwa pomocy archiwalnych) informacji zawartych w aktach, a następnie poddanie eksperymentowi wybranej grupy osób, których zadaniem było wytypowanie, w których jednostkach archiwalnych, na podstawie pomocy archiwalnych dana informacja się znajduje. I tak w badaniu zostały wykorzystane następujące metody badawcze: metoda reprezentacyjna, eksperyment oraz metody matematyczne. Uzyskane dane liczbowe posłużyły do obliczenia wskaźników efektywności informacyjnej stanowiących podstawę analizy systemowej Archiwum Państwowego w Toruniu. Trzonem ar- 
tykułu jest próba praktycznego sprawdzenia, czy obliczenie współczynników efektywności informacyjnej może dostarczyć danych mających realny wpływ przy ocenie systemu. Badanie pozwoliło ocenić w większym lub mniejszym stopniu wszystkie elementy systemu informacji archiwalnej i dla każdego z badanych zespołów archiwalnych wyciągnąć wnioski wskazujące elementy, których modyfikacja mogłaby polepszyć działanie systemu. Obliczenie wskaźników pozwoliło w sposób dokładny ocenić użyteczność poszczególnych pomocy archiwalnych i wysunąć wniosek, że na efektywność wyszukiwania informacji istotny wpływ miało wprowadzenie w 2002 roku wskazówek uproszczonego opracowania zasobu archiwalnego.

\section{UWAGI WSTĘPNE}

Co, najprościej ujmując, decyduje o tym, czy użytkownik, wychodząc z archiwum, uważa cel swojej wizyty za osiągnięty, czy też nie? Odpowiedź może być jedna, zależne jest to od tego, czy odnalazł informację, której poszukiwał. Dlatego też archiwiści powinni dążyć do tego, aby wszystkie elementy systemu, jakim możemy nazwać archiwum, zaspokajały potrzeby informacyjne użytkowników. System, który powinien służyć do wyszukiwania, a następnie udostępniania informacji, nosi nazwę systemu informacji archiwalnej. Kolejne nasuwające się natychmiast pytanie brzmi: ale w jaki sposób go zbadać? Archiwistyka dysponuje szeroką listą metod badawczych, służących badaniu dziedziny archiwalnej, niektóre z nich są bardziej powszechne, inne mniej, a niektóre są wręcz nowatorskie. Za sprawą publikacji Bohdana Ryszewskiego Problemy $i$ metody badawcze archiwistyki ${ }^{1}$ celem dla mnie stała się próba zbadania systemu informacji archiwalnej przy pomocy metod do tej pory w archiwistyce nieużywanych. Kolejne strony niniejszego artykułu mają pomóc odpowiedzieć na pytanie, czy wybrane metody badawcze można wykorzystać w praktyce, a przede wszystkim czy wyniki badania pozwolą wyprowadzić wnioski, mogące w realny sposób być przyczynkiem do ulepszenia systemu informacji archiwalnej. Oczywiście badanie trzeba było okroić do jednego archiwum, gdyż przeprowadzenie badania systemu informacji archiwalnej na większej liczbie jednostek, czy też całej sieci archiwalnej, jest niemożliwe, koszty jego wykonania przerastają możliwości jednej osoby. W ten sposób do badania zostało wytypowane - jako najbliżej położone - Archiwum Państwowe w Toruniu.

${ }^{1}$ B. Ryszewski, Problemy i metody badawcze archiwistyki, Toruń 1985. 


\section{CO TO JEST SYSTEM INFORMACJI ARCHIWALNEJ?}

Rozważania dotyczące systemu informacji archiwalnej należy zacząć od zdefiniowania terminu system, co ułatwi przełożenie i zastosowanie tej definicji na gruncie archiwistyki. W literaturze naukowej spotyka się bardzo wiele określeń terminu system, jednak trzeba podkreślić, że dopiero nauki systemowe określiły definicje, system pojęć i metody badawcze, związane z podejściem systemowym, stosowanym przez naukowców w stosunku do badanych przez nich przedmiotów ${ }^{2}$. Postaram się przytoczyć kilka znalezionych definicji systemu, podkreślając, że niemal w każdej publikacji można znaleźć inaczej skonstruowane określenie interesującego terminu, jednak nie różnią się one znaczeniem. Jak się za chwilę okaże, charakteryzuje je taki sam zestaw cech, a jedyną różnicą jest mniejsze lub większe akcentowanie znaczenia poszczególnych z nich. Stosowanie terminu system stało się bardzo popularne, a to dlatego, że ujęcie systemowe pozwala spoglądać na obiekty badań całościowo i kompleksowo, pozwala lepiej rozumieć otaczające nas zjawiska.

Słowo system jest synonimem słowa porządek, a przeciwstawny jemu jest chaos - gdy na dany proces mają wpływ niezależne od nas i niemożliwe do przewidzenia czynniki. Według Z. Gładysa i W. Pogorzelskiego system to „określona kombinacja czynników współzależnych i współpracujących dla osiągnięcia wspólnego celu"', podobny nacisk położony na cel przedstawia definicja „system to zbiór metod i środków rozwiązania jakiegoś problemu”“4. Kolejne definicje ukierunkowane są na powiązanie całościowe elementów systemu, i tak na przykład jest to „zbiór obiektów rzeczywistych lub wirtualnych

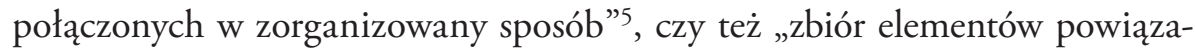
nych w taki sposób, że tworzą one pewną nową całość wyróżniającą się w otoczeniu”. Jeszcze bardziej rozbudowana definicja określa system jako „zbiór

2 Tamże, s. 74.

${ }^{3}$ Z. Gładys, W. Pogorzelski, Elementy analizy systemowej, Płock 2002, s. 20.

${ }^{4}$ M. Gołembiowski, System i informacji archiwalnej, Warszawa-Łódź 1985, s. 81.

5 J. M. Pomykała, J. A. Pomykała, Systemy informacyjne. Modelowanie i wybrane techniki kryptograficzne, Warszawa 1999, s. 15, cyt. za: M. Kisilowska, Modelowanie rozlegtych systemów informacyjnych. Zdrowie i kultura, Warszawa 2009, s. 51.

${ }^{6}$ A. Rosa, Archiwa między historiq i pamięcia. Antropologizowanie archiwistyki, [w:] Archiwa-Kancelarie - Zbiory, t. 2, red. W. Chorążyczewski, R. Degen, K. Syta, Toruń 2008, s. 124. 
obiektów i relacji między nimi i ich atrybutami, powiązanych wzajemnie, a także z otoczeniem, do tego stopnia, że tworzą całość"7.

Omawianie istoty ujęcia systemowego trzeba zacząć od pojęcia element, który to, wchodząc w ściślejsze relacje z jednym bądź wieloma elementami, tworzy podsystem danego systemu. Jeśli dany podsystem będziemy ujmowali jednostkowo, możemy wtedy mówić o systemie niższego rzędu, ważne jest też zauważanie nadsytemów, które to często tworzą kontekst istnienia badanego systemu, gdyż to od nich pochodzą zadania mu stawiane i tworzą się powiązania z innymi systemami tego nadystemu ${ }^{8}$. System rozpatrujemy jako całość, ponieważ między poszczególnymi elementami występują sprzężenia, relacje te mogą odbywać się bezpośrednio lub pośrednio. Aby system mógł funkcjonować i nawiązywać relacje z otoczeniem musi być wyposażony w wejście i wyjście. Podkreślić należy, że systemu nie można rozumieć jako obiektu fizycznego, który podlega badaniu, jest to w pełni twór abstrakcyjny, powstały po to, by pomóc nam zbadać obiekt ${ }^{9}$.

Aby uświadomić sobie istotę podejścia systemowego, aby poprawnie przeprowadzić badanie, trzeba poznać główne cechy rządzące takim ujęciem rozpatrywanych przez nas zjawisk. Najważniejsze w tym przypadku jest podejście holistyczne, czyli rozpatrywanie badanego przez nas obiektu jako całości, nigdy jako sumy elementów składowych, ponieważ są one jedynie częścią nierozerwalnej całości. Badając system, skupiamy się na jego własnościach funkcjonalnych, nie jest tak ważna struktura, jak procesy zachodzące, i dlatego też oderwane od całości części składowe przestają istnieć, przestają być „nośnikiem” procesu. Dlatego też system musi być przez badacza traktowany kompleksowo, ujawniać wszelkie sprzężenia i relacje między elementami, a także kontekstowo, czyli w jego relacjach z otoczeniem. Aby ocenić funkcjonowanie systemu jako dobre czy też złe, musimy znać cel, na jaki jego istnienie jest zorientowane, i wtedy też możemy zbadać efektywność działania systemu, która w zależności od przedmiotu badania i wspomnianego już celu może być inaczej rozpatrywana ${ }^{10}$.

7 P. P. Schoderback, C. G. Schoderback, A. G. Kefalas, Management systems, Homewood 1990, cyt. za: M. Kisilowska, Modelowanie rozlegtych systemów informacyjnych. Zdrowie i kultura, Warszawa 2009, s. 50.

${ }^{8}$ Z. Gładys, W. Pogorzelski, dz. cyt., s. 21.

9 B. Ryszewski, dz. cyt., s. 75-77.

10 Z. Gładys, W. Pogorzelski, dz. cyt., s. 34-36, 53-57. 
Bohdan Ryszewski definiuje system informacji archiwalnej jako „pewne uporządkowanie pomocy ewidencyjno-informacyjnych i pomocy archiwalnych zrobione w taki sposób, aby użytkownik [...] pokonywał [...] bariery dzielące go od poszukiwanych archiwaliów”. Sam autor stwierdza, że taka definicja ogranicza nasze badanie jedynie do wymienionej wyżej pomocy i dlatego proponuje w tym przypadku skorzystać z dorobku informacji naukowej, gdzie system obsługi informacyjnej łączy w sobie system wyszukiwawczy oraz udostępniania ${ }^{11}$. Poza tym uważam, że definicja Ryszewskiego nie obejmuje jednej z głównych cech, jaką powinien charakteryzować się system, czyli obecności stałych elementów, jakimi są wejście i wyjście, jest ona hermetycznie zamknięta na pomoce i chociaż jest tu mowa o dotarciu do informacji poszukiwanych przez użytkowników, te dwa elementy nie są w tym przypadku od siebie zależne, nie współgrają. Wymienione powody skłaniają mnie do uznania za bardziej poprawną definicję wyprowadzoną przez M. Gołembiowskiego, a brzmiącą następująco: system to „zbiór powiązanych ze sobą elementów, przeznaczonych do odnalezienia w dokumentacji archiwalnej (czyli w archiwalnych zbiorach informacji) tej informacji, która będzie odpowiadała na pytania postawione systemowi, oraz udostępniania jej użytkownikowi” ${ }^{2}$. Dzięki temu badany przez nas system informacji archiwalnej poszerza się o zakres wyszukiwania i udostępniana.

Dzięki skorzystaniu z dorobku informacji naukowej, w systemie informacji archiwalnej możemy wydzielić dwa podsystemy: wyszukiwawczy i udostępniania, które opiszę osobno i dlatego też będę je nazywać systemami. Wyszukiwanie polega na odnajdywaniu informacji w danym zbiorze, odpowiadającej zapytaniu użytkownika. Udostępnianie jest doprowadzaniem informacji do użytkownika, umożliwieniem dostępu do źródeł informacji lub też udzieleniem odpowiedzi faktograficznej. Najważniejszym sposobem oceny systemu jest zbadanie jego efektywności, a żeby ją zbadać, musimy znać cel funkcjonowania systemu, trzeba przy tym pamiętać, że efektywność systemu udostępniania a efektywność systemu wyszukiwania nie są tym samym. Wyszukiwanie ma na celu osiągnięcie odpowiedzi zgodnej z zapytaniem informacyjnym (stosunek między dokumentem wyszukanym a pytaniem), za to istotą udostępniania powinno być uzyskanie odpowiedzi zgodnej z potrzebą użytkownika. B. Ryszewski o celach systemu udostępniania rozstrzyga na-

11 B. Ryszewski, dz. cyt., s. 129-131.

12 M. Gołembiowski, dz. cyt., s. 82. 
stępująco: zaspokojenie potrzeby informacyjnej w teorii informacji naukowej spoczywa na obsłudze informacyjnej, a skoro składa się ona z dwóch omawianych systemów, to funkcja ta powinna przypaść właśnie udostępnianiu ${ }^{13}$. Uważam jednak, że odpowiedzialność za spełnienie potrzeby informacyjnej spoczywa również na systemie wyszukiwawczym, język informacyjno-wyszukiwawczy, a co za tym idzie zbiór źródeł pochodnych (pomoce archiwalne), powinny być dostosowane do użytkownika, reagować nie tylko na jego zapytania, ale i potrzeby.

Potrzeba informacyjna użytkownika jest pojęciem szerszym od zapotrzebowania informacyjnego (pytania), nie muszą się one pokrywać. Stosunek potrzeby do zapotrzebowania jest zależny od użytkownika - stopnia jego przygotowania, znajomości interesującego go tematu. Wystosowanie do systemu wyszukiwawczego pytania odpowiadającego potrzebie, a zarazem dostosowanego do języka informacyjno-wyszukiwawczego, może sprawiać trudności. Zadanie niwelowania tych niezgodności powinno spoczywać na systemie obsługi informacyjnej, a przede wszystkim na systemie udostępniania, na barkach którego leży: badanie potrzeb użytkowników, rozpowszechnianie informacji oraz informacja adresowana ${ }^{14}$. Gdy użytkownik otrzyma informację zgodną z jego potrzebą, będzie to pertynentność - otrzymał informację odpowiednią, za to relewantnością nazwiemy zgodność z zapotrzebowaniem informacyjnym (informacja trafna), w której dodatkowo możemy rozróżnić jej dwa rodzaje, czyli relewantność znaczeniową i formalną, ta pierwsza oznacza zgodność odpowiedzi z pytaniem, druga zgodność z instrukcją wyszukiwawczą, czyli z tekstem wyrażonym w języku informacyjno-wyszukiwawczym ${ }^{15}$.

\section{JAK BADAĆ SIA, CZYLI O ANALIZIE SYSTEMOWEJ SEÓW KILKA}

Według Zbigniewa Gładysa i Witolda Pogorzelskiego przy podejściu systemowym nie możemy mówić o metodach badań specjalnie w tym przypadku wykształconych, korzysta się raczej z metod kombinowanych innych dziedzin naukowych. Dzieje się tak, gdyż ujęcie systemowe nie ma swojego własnego przedmiotu, dostosowuje się do dyscypliny naukowej, która ją w danym przy-

13 Tamże, s. 84-92; B. Ryszewski, dz. cyt., s. 110-111.

14 B. Ryszewski, dz. cyt., s. 112.

15 M. Gołembiowski, dz. cyt., s. 85, 92-93. 
padku wykorzystuje ${ }^{16}$. Dla przypomnienia, podejście systemowe charakteryzuje się głównie tym, że pozwala spojrzeć całościowo na dany, wyróżniony na pewnym poziomie abstrakcji system - obiekt badania, zarazem dostrzegając elementy na niego się składające wraz z ich wzajemnymi powiązaniami i dlatego możemy mówić o analizie systemowej jako o głównej metodzie stosowanej w badaniach systemów. Analiza systemowa ma za zadanie rozpatrywać badany obiekt jako system, dzięki czemu respektuje wszelkie zasady podejścia systemowego oraz cechy, jakimi musi się dany system charakteryzować. I tak analiza systemowa „pozwala potraktować badany problem całościowo, jednocześnie uwzględniając wszystkie obiekty występujące w badanym systemie, ich strukturę wewnętrzną, formy istnienia i funkcjonowania, relacje między różnymi obiektami, efektywność systemu, a także wpływ otoczenia na system i wpływ systemu na otoczenie oraz związki między systemami różnego rzędu"17. Dzięki temu krótkiemu omówieniu modelu analizy systemowej możemy z łatwością zrozumieć, co różni ją od zwykłej metody analitycznej. Analiza wyodrębnia poszczególne elementy i je bada, za to analiza systemowa bada efekt oddziaływania między elementami, przez co łączy je w pewną całość. Jednak możemy spotkać się z poglądem sprzeciwiającym się ujęciu tej metody w ramy klasycznie rozumianej metody naukowej, podkreślając jej uniwersalizm jako kombinacji rozsądnie zestawionych reguł myślowych, sztuki czy raczej umiejętności stawiania pytań i szukania nań sensownych odpowiedzi ${ }^{18}$, z czym się zgadzam. Poniżej omówiona analiza systemu informacji archiwalnej jest tylko propozycją przeprowadzenia takiego badania, nic nie stoi na przeszkodzie innego jego zrealizowania, pod warunkiem że będzie to badanie logicznie skonstruowane i wykonane.

Analiza systemowa może mieć różny charakter, wyróżniamy analizę jakościową i ilościową, z czego ta pierwsza może być identyfikacyjna (zawierająca opis obiektu) lub problemowa, czyli zawierająca opis problemowy obiektu. Stosując analizę ilościową, możemy wyróżnić w tym przypadku jej odmianę matematyczną lub ilościowo-statystyczną ${ }^{19}$. Ponadto stosowany przez nas model analizy systemowej może mieć sens poznawczy lub metodologiczny. Charakter poznawczy ukierunkowany jest na wyróżnienie i badanie konkret-

16 Z. Gładys, W. Pogorzelski, dz. cyt., s. 23.

${ }^{17}$ A. Rosa, dz. cyt., s. 124.

${ }_{18}$ Z. Gładys, W. Pogorzelski, dz. cyt., s. 53-57.

19 W. Kieżun, Podstawy organizacji i zarządzania, Warszawa 1977, s. 216-217, cyt. za: B. Ryszewski, dz. cyt., s. 78. 
nych systemów, służących ich poznaniu, a następnie ulepszeniu. Wyznaczenie przebiegu analizy należy do metodyki, a wnioski mają użyteczność przede wszystkim praktyczną, chociaż mogą mieć walory naukowe. I głównie z taką analizą mamy do czynienia przy badaniu działalności archiwalnej, czyli obejmując badaniem strukturę organizacyjną archiwum, warunki, w jakich działa, zasób, funkcje i czynności. Ten rodzaj analizy może posłużyć również do badania systemu informacji archiwalnej. Analiza systemowa o zakresie metodologicznym nastawiona jest na jak najgłębsze poznanie badanego obiektu, co prowadzić ma do wzbogacenia teorii danej nauki. Polegało to będzie na wyodrębnieniu i zbadaniu systemu, rozwiązaniu problemu badawczego, który prowadzi do sformułowania wniosków, poddanych następnie weryfikacji przez porównania z innymi przykładami czy też twierdzeniami, w tym przypadku archiwistyki i dziedzin pokrewnych, które są podstawą do weryfikacji teorii, tu: teorii archiwistyki ${ }^{20}$.

Analiza systemowa może mieć różnoraki przebieg, ja podam tylko jej przykład, który może być zastosowany do zbadania systemu informacji archiwalnej. Etap pierwszy powinien obejmować ustalenie problemu, który będzie celem analizy oraz zakresu jego badania, czyli elementów, sprzężeń, podsystemów i planu badania, czyli kwestionariusza badawczego i opracowanie sposobów zbierania danych. Etap drugi polega na badaniu problemu w systemie, czyli opisie elementów i sprzężeń wyodrębnionych w dotychczasowym ich działaniu, następnie badamy wpływ otoczenia, w tym wpływ systemu wyższego rzędu (środowiska archiwalnego) na system. Czynnością końcową dla tego etapu powinna być analiza danych opisu. Na podstawie wyciągniętych z tej analizy wniosków następuje modyfikacja systemu, jego poszczególnych składników mających wartość dla badanego problemu, działanie to jest przedmiotem etapu trzeciego badania. Ostatnim etapem będzie ocena i weryfikacja wyprowadzonego modelu, czyli porównanie go z praktyką czy też opublikowanymi wynikami podobnie przeprowadzonych lub poruszających ten sam problem badań. Jeśli dodatkowo odniesiemy uogólnienia do twierdzeń archiwistyki i nasze badania opublikujemy, wtedy możemy mówić o analizie systemowej w wersji metodologicznej ${ }^{21}$.

Przedmiotem badań - elementami systemu informacji archiwalnej, zgodnie z metodą analizy systemowej, w przyjętym systemie będą:

20 B. Ryszewski, dz. cyt., s. 78.

21 A. Rosa, dz. cyt., s. 126-127; B. Ryszewski, dz. cyt., s. 79-82. 
1. zbiór źródeł pierwotnych,

2. opracowanie tego zbioru,

3. zbiór informacji pochodnych,

4. użytkownicy informacji archiwalnej,

5. udostępnianie,

6. rozpowszechnianie,

7. wyszukiwanie.

Ostatni element, czyli wyszukiwanie, stanowi niejako podsumowanie i daje obraz działania całego systemu, gdyż jego badanie obejmuje następujące elementy: użytkownicy systemu, zbiór informacji pochodnych, pracowników archiwum i zbiór informacji pierwotnych oraz sprzężenia między nimi. Przedmiot badań może być w tym wypadku zakreślony szerzej, odnosić się do wszelkich archiwów, ich sieci, ale zgodnie z tematem niniejszego artykułu będą to badania zakreślone wąsko, odnoszące się do jednego archiwum. Opisanie zbioru źródeł pierwotnych może uwzględniać takie elementy jak: kryterium podziału zasobu i wyodrębnienie zespołów, układ zespołów i struktura zasobu. Zajmując się zasadami opracowania tego zbioru, powinniśmy mieć na uwadze przynajmniej język informacyjny i reguły opracowania archiwalnego oraz metody wyboru rodzaju i formy informacji pochodnej dla każdego zespołu. Zbiór informacji pochodnych powinien być opisany według rodzajów pomocy ewidencyjno-informacyjnych, co prowadzi do ustalenia struktury zbioru i jego końcowej oceny jako całości. Użytkownicy powinni być jak najwnikliwiej opisani, a ich potrzeby zbadane, niezbędne jest określenie liczby użytkowników i wypożyczeń w określonym czasie, ponadto można badać strukturę korzystających z zasobu przez analizę według podziału na różne kategorie, np. według przygotowania, specjalności, dziedziny, którą reprezentują itp. Opis udostępniania w ramach tego badania powinien objąć przepisy i metody udostępniania w pracowni naukowej, a także wnioski z obserwacji personelu, czas i częstotliwość udostępniania materiałów w pracowni naukowej. Rozpowszechnianie jest w tym wypadku wydzielone z udostępniania i oznacza działania i formy opracowywania informacji selektywnej, kierowanej do ogółu lub adresowanej ${ }^{22}$. Element ten został pominięty w moich badaniach, gdyż przeprowadziłam je na wybranej grupie użytkowników bezpośrednio wyszukujących informacje.

22 B. Ryszewski, dz. cyt., s. 79-82, 122-133. 


\section{METOdY GROMADZENIA DANYCH DO ANALIZY SYSTEMOWEJ SIA}

Badanie systemu informacji archiwalnej polega na analizie poszczególnych jej elementów i, jak już wcześniej opisywałam, ostatni z nich, czyli wyszukiwanie, stanowi połączenie całego pola badań, pozwala ocenić proces informacyjny, zachodzący w omawianym systemie, dlatego też skupiłam uwagę na badaniu podsystemu wyszukiwawczego. Najistotniejszym czynnikiem, wpływającym na ocenę działania tego systemu, a co za tym idzie i systemu informacji archiwalnej, interpretowanym za informacją naukową jako system obsługi informacyjnej, jest zbadanie efektywności informacyjnej. Możemy ją tłumaczyć za Bohdanem Ryszewskim jako skuteczność informacji, czyli relację między wynikami działalności informacyjnej a jej założonymi celami; przejawia się ona w tzw. wskaźnikach efektywności informacyjnej, o których mowa będzie w następnych podrozdziałach ${ }^{23}$. Dla zbadania interesującego nas przedmiotu i wyciągnięcia wniosków potrzebne jest zebranie danych. W przeprowadzonym przeze mnie praktycznym badaniu efektywności informacyjnej posłużę się trzema metodami badawczymi, są to: eksperyment, metoda reprezentacyjna i statystyczna. Aby ich użyć poprawnie, niezbędne jest poprzedzające praktykę teoretyczne zapoznanie się z nimi.

\section{EKSPERYMENT}

Eksperyment może być określany jako doświadczenie prowadzone w celu wywołania określonego zjawiska, w warunkach naturalnych lub laboratoryjnych, dla zbadania jego przebiegu, a także wyniku końcowego ${ }^{24}$. I właśnie cechą charakterystyczną tej metody badawczej jest czynna ingerencja w przedmiot badania; badacz modyfikuje zjawisko badane, ma wpływ nie tyle na przebieg badania, co na czynniki wpływające. Środki, za pomocą których ingeruje się w przedmiot poddany badaniu, nazywamy zmienną niezależną lub czynnikiem eksperymentalnym. Zmienną zależną lub skutkiem nazywamy element, który w wyniku zaistniałej ingerencji uległ zmianie. Celem eksperymentu jest poznanie zależności przyczynowo-skutkowej między określonymi

23 Tamże, s. 134-135.

${ }^{24}$ K. M. Czarnecki, Metodologiczne podstawy naukowego rozwoju studentów, Sosnowiec 2009, s. 74. 
zmiennymi, między czynnikiem sprawczym a rezultatem, jaki nastąpi w wyniku ingerencji w badane zjawisko, które w warunkach obserwacji, czyli biernej postawy badacza, nie zostałoby poznane. Eksperymenty można przeprowadzać jedynie nad zjawiskami powtarzalnymi, logiczne jest, że nie można kontrolować, ingerować w zjawiska indywidualne, gdyż nie znamy ich przebiegu $^{25}$. W metodzie eksperymentalnej według K. M. Czarneckiego wyróżniamy cztery techniki badawcze: eksperyment jednogrupowy, grup porównawczych, rotacyjny i grup wyrównawczych. Wśród wymienionych interesuje nas pierwsza z nich, gdyż próba zbadania efektywności informacyjnej odbędzie się właśnie na jednej grupie. Przebieg takiego eksperymentu wygląda następująco: grupie osób ustala się stan wyjściowy określonej sytuacji (temat, do którego mają w zasobie odnaleźć informację), następnie wprowadza się do tej grupy określony czynnik (w tym przypadku będzie to określona pomoc archiwalna, charakteryzowana za pomocą języka informacyjnego, w którym została stworzona) i to jego wpływ na przebieg zjawiska określa wynik końcowy doświadczenia (jednostki odpowiadające tematowi, wytypowane przez uczestników doświadczenia na podstawie pomocy ewidencyjno-informacyjnej). Wynik eksperymentu na jednej grupie można łatwo ujmować za pomocą metod statystycznych ${ }^{26}$.

Bohdan Ryszewski proponuje kilka sposobów zbadania efektywności informacyjnej danego systemu informacji archiwalnej, wzorowane są one głównie na metodzie W. Lancastera, przygotowanej dla systemów bibliotecznych, które wg Ryszewskiego mogą być zaadaptowane dla archiwistyki. Efektywność informacyjną, jak już wspominałam, można zbadać, obliczając wskaźniki efektywności, potrzebne dane zbierane są w momencie, gdy użytkownik kieruje pytanie do zbioru źródeł przy pomocy źródeł pochodnych i otrzymuje na nie odpowiedź. Wśród wszystkich wyszukanych przez użytkownika źródeł możemy mówić o tych wyszukanych trafnie, odpowiadających na jego pytanie, jednak nie muszą (i często też nie są) to być wszystkie źródła, odpowiadające na pytanie zadane systemowi. I właśnie o kompletności możemy mówić, gdy użytkownik wyszukał wszystkie dokumenty relewantne w zbiorze. Na podstawie zebranych danych, dotyczących ilości poszczególnych z tych źródeł, możemy obliczać wskaźniki efektywności.

25 J. Pieter, Zarys metodologii pracy naukowej, Warszawa 1975, s. 81-88.

26 K. M. Czarnecki, dz. cyt., s. 85-88. 
Przed przystąpieniem do badania ważne jest ustalenie, czy badamy zgodność odpowiedzi systemu wyszukiwawczego na potrzebę, czy pytanie informacyjne, czy badamy relewantność, czy też trafność znaczeniową odpowiedzi. Dużo łatwiej jest przeprowadzić badanie drugiego z omawianych wariantów, gdyż sprawdza opracowanie charakterystyk wyszukiwawczych w pomocach archiwalnych i prawidłowość instrukcji archiwalnych. Ocena zgodności wyszukania z potrzebą informacyjną również składa się z wyżej wymienionych wskaźników, lecz ponadto może być określona dopiero po zapoznaniu się użytkownika z treścią danej jednostki archiwalnej odnalezionej w zespole. Trudność może sprawiać ocena rozbieżności między potrzebą a pytaniem zadanym przez użytkownika, co jest dla niego procesem intuicyjnym, zależnym od wielu czynników, np. od wykształcenia.

Przy użyciu tej metody głównym zadaniem jest ustalenie trzech typów danych: liczby wszystkich źródeł wyszukanych w odpowiedzi na dane pytanie, liczby źródeł wyszukanych trafnie oraz liczby wszystkich źródeł w zbiorze odpowiadających na dane pytanie (źródeł relewantnych). Ryszewski proponuje trzy metody przeprowadzenia badania, każda z nich opiera się na testach, skierowanych do użytkowników lub obsługi, i powinny być one powtarzane wielokrotnie, na różnych grupach (zespołach) materiałów archiwalnych i przy innym doborze osób biorących udział w eksperymencie, co jest jednak zabiegiem bardzo kosztownym, wymagającym dużego nakładu pracy i czasu. Pierwsze badanie przebiega następująco: najpierw formułujemy temat poszukiwań, następnie wybieramy pomoc archiwalną, w której będziemy poszukiwać dokumentów, odpowiadających naszemu pytaniu, narzędziem badawczym będzie tu ankieta lub też wywiad i ankieta, gdy użytkownik nie wypełnia kwestionariusza ankiety sam, a robi to osoba przeprowadzająca eksperyment. Kwestionariusz może wyglądać następująco:

Rysunek 1. Wzór kwestionariusza do badania trafności i kompletności informacyjnej

\begin{tabular}{|c|c|c|}
\hline \multicolumn{3}{|c|}{ 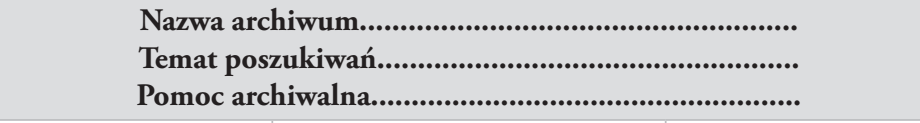 } \\
\hline Odpowiedzi & Trafna & Nietrafna \\
\hline Wydane & & \\
\hline Niewydane & & X \\
\hline
\end{tabular}

Źródło: B. Ryszewski, Problemy i metody badawcze archiwistyki, Toruń 1985, s. 145. 
W tym przypadku łatwo jest określić ilość jednostek archiwalnych trafnie lub nietrafnie wydanych, ale bardzo trudno będzie określić, ilu jednostek trafnych system nie wydał, utrudnione jest określenie wskaźnika kompletności. Wyjściem mogą tu być ponowne, pogłębione poszukiwania o jednostki opisane ogólnikowo, stwarza to szansę odnalezienia dokumentów trafnych niewydanych przy pierwszej kwerendzie. Alternatywę stanowi propozycja Charlesa Meadowa ${ }^{27}$, wspomniana przez B. Ryszewskiego. Proponuje on po pierwszym wyszukiwaniu skierować do systemu pytanie bardziej ogólne o zwiększonym zakresie. Meadow zakłada, że w ten sposób odnajdziemy w zbiorze wszystkie relewantne odpowiedzi, a suma wielu zebranych odpowiedzi pozwoli na ocenę efektywności informacyjnej danej pomocy archiwalnej.

Według B. Ryszewskiego znacznie dokładniejszy wynik otrzymamy, stosując metody eksperymentu, opisane przez W. Lancastera. Pierwsza z nich zaczyna się od wybrania ze zbioru źródeł pierwotnych jednolitej tematycznie grupy dokumentów, którą przedstawiamy użytkownikowi, specjalizującemu się w danej dziedzinie. Jego zadaniem jest sformułowanie pytania odpowiadającego treści wszystkich dokumentów wcześniej wybranych. Czynność ta powinna być powtórzona z innym użytkownikiem - specjalistą, dla skontrolowania poprawności wyprowadzonego pytania. Kolejna osoba wyszukuje dokumenty według niego odpowiadające pytaniu w systemie wyszukiwawczym na podstawie wszystkich dostępnych pomocy archiwalnych. Otrzymany wynik - liczbę dokumentów wyszukanych przez system porównujemy z liczbą dokumentów odpowiadających pytaniu, co zostało ustalone już wcześniej, w ten sposób ustalamy wskaźnik kompletności. Wskaźnik trafności ustala się na podstawie oceny użytkownika, który sformułował pytanie co do trafności dokumentów wyszukanych.

Drugi wariant badania, nieco zmieniony, zaczyna się od sformułowania zapytania przez użytkownika, który następnie wybiera z danego zbioru źródeł pierwotnych dokumenty odpowiadające pytaniu. Następna grupa użytkowników lub też osoby należące do obsługi archiwalnej wybierają wyszukane przez siebie dokumenty pokrewne treściowo, które dołącza się do sformowanej wcześniej grupy. Z tak zebranej grupy źródeł użytkownik formułujący pytanie odrzuca według niego dokumenty nietrafne i w ten sposób powstaje grupa o pełnej trafności. Dalszy przebieg badania jest powtórzeniem

27 Ch. Meadow, Analiza systemów informacyjnych, Warszawa 1972, s. 161, cyt. za: B. Ryszewski, dz. cyt., s. 146. 
eksperymentu poprzedniego. Końcowy wynik pozwala ustalić współczynnik kompletności oraz trafności.

Wyniki wielokrotnie powtórzonych badań można umieszczać na osi współrzędnych w formie procentowej, gdzie jedna oś odpowiada kompletności, druga przyporządkowana jest trafności. Przy dużej skali powtórzeń badania można ustalić zależność między kompletnością a trafnością informacji odszukanej. Jednakże wyników nie będzie można uznać za całkowicie zadawalające, jest rzeczą niemożliwą skontrolowanie całego zasobu archiwalnego danego archiwum, końcowy wynik zawsze będzie liczbą mniej lub bardziej przybliżoną. Ponadto tak przeprowadzone eksperymenty opierają się na subiektywnej ocenie oraz przygotowaniu użytkowników ${ }^{28}$. Obie metody jednak nie do końca pokrywają się z praktyką archiwalną, z czego mamy wybierać jednorodną tematycznie grupę dokumentów, a może poprawniej będzie mówić o jednostkach archiwalnych? Z całego zasobu danego archiwum? $\mathrm{Na}$ jakiej podstawie wybrać specjalistę biorącego udział w eksperymencie? Aby przeprowadzić taki rodzaj badania, musi być ono bardziej dostosowane do specyfiki archiwistyki. Podjęcie tej próby zostanie opisane w dalszej części artykułu.

\section{Metoda REPREZENTACYjNA}

Przeprowadzenie eksperymentu, mającego na celu zbadanie funkcjonowania systemu wyszukiwawczego, wymaga od badacza wytypowania pewnej grupy dokumentów poddanej badaniu. Niemożliwe jest zbadanie całego zasobu archiwalnego danego archiwum, byłoby to nad wyraz czasochłonne, dlatego przed przystąpieniem do eksperymentu trzeba wytypować zespół, czy też pewną liczbę zespołów archiwalnych, pozwalających poprawnie ocenić cały system informacji archiwalnej. Problemem jest wytypowanie takiego zbioru, aby badania przeprowadzone na nim, uzyskane wyniki i wysunięte wnioski były reprezentatywne, wiarygodnie orzekały o całości zasobu danego archiwum. W takim przypadku pomocne jest stosowanie metod reprezentacyjnych, czyli badań polegających na wyborze próby z całej badanej przez nas zbiorowości. Przed przystąpieniem do tak prowadzonych badań należy zapoznać się z rodzajami prób i metodami ich doboru. Mogłoby się wydawać, że losowanie jest tożsame z dowolnością i chaosem, jednak po zagłębieniu się w literaturę tematu można z całą pewnością orzec, że pobieranie prób rządzi

${ }^{28}$ B. Ryszewski, dz. cyt., s. 129-150. 
się wieloma regułami, które dla laika w dziedzinie wnioskowania statystycznego są trudne do zrozumienia.

Dobór próby składa się z następujących etapów ${ }^{29}$ :

- zdefiniowanie populacji, czyli zbiorowości generalnej, definiowanej, jako wyodrębnionego zbioru obiektów, różniącymi się wartościami jakiejś cechy ${ }^{30}$ (w tym przypadku będzie to zasób Archiwum Państwowego w Toruniu),

- określenie jednostki próby, może to być jednostka danej populacji lub zbiory tych jednostek, zawierające określone cechy badane (jednostka archiwalna),

- określenie operatu losowania, jest to wykaz jednostek losowania, operat musi być kompletny, obejmujący wszystkie jednostki danej populacji, przy czym każda jednostka może w nim figurować tylko raz ${ }^{31}$,

- wybór metod losowania, może to być dobór losowy (z zastrzeżeniem, że każda jednostka ma takie samo prawdopodobieństwa wylosowania) lub wybór nielosowy,

- określenie liczebności próby, zależny od liczebności badanej populacji, zmienności badanej cechy oraz poziomu dokładności, z jakim prowadzone są badania,

- dobór próby, który powinien być w pełni zaplanowany.

Metoda reprezentacyjna to nie tylko wybór losowy próby, może to być również wybór celowy, gdy elementy wybrane są zgodnie z wolą badacza, jednak przy tak przeprowadzonym badaniu istnieje dużo większe niebezpieczeństwo wyprowadzenia błędnych wniosków, gdyż zatracona zostaje istota tej metody, czyli takiego wyboru cząstki, który będzie stanowić trafną reprezentację całej badanej zbiorowości ${ }^{32}$. Losowanie próby może przebiegać w jednej lub w kilku turach, mówimy wtedy o losowaniu jednoetapowym lub wieloetapowym. Najprostszą z istniejących metod jest losowanie proste, prowadzone w jednym etapie, gdy ze zbiorowości generalnej, niedzielonej na grupy, losujemy kolejno elementy próby. W takim przypadku mamy do czy-

${ }^{29}$ M. Mróz, S. Sirko, Elementy statystyki w badaniach naukowych, [w:] Metody, techniki i narzędzia badawcze oraz elementy statystyki stosowane w pracach magisterskich i doktorskich, red. M. Cieślarczyk, Warszawa 2003, s. 70.

${ }^{30}$ A. Burzyński, Elementy statystyki dla historyków: materiaty do ćwiczeń, wyktadów i metodyki prac badawczych, t. 1, Kraków 1980, s. 230.

31 R. Zasępa, Metoda reprezentacyjna, Warszawa 1972, s. 24.

${ }^{32}$ M. Mróz, S. Sirko, dz. cyt., s. 72-73. 
nienia $\mathrm{z}$ losowaniem indywidualnym (jednostka losowania jest zarazem jednostką badania). Losowanie proste może być przeprowadzone dwojako, może to być losowanie niezależne (ze zwracaniem), gdy wylosowana jednostka jest zwracana z powrotem do populacji i może być wybrana po raz kolejny (stałe prawdopodobieństwo wyboru), lub może to być losowanie zależne (bez zwracania), gdy jednostka wylosowana nie uczestniczy już w dalszym losowaniu, może być wybrana tylko raz (prawdopodobieństwo wylosowania zmienia się z każdym kolejnym doborem) ${ }^{33}$. Jeśli nie losujemy pojedynczych jednostek badania, a losujemy podzbiory, składające się z tych jednostek, to jest to losowanie zespołowe.

Podzbiór rozłączny z resztą populacji nazwiemy warstwą, musi ona spełnić kilka warunków: powinna być odpowiednio liczna, kryterium doboru do niej elementów musi być jednoznaczny, a ich liczba musi być znana, ponadto elementy w warstwie musi charakteryzować jednorodność pod względem określonej cechy, wyróżniającej ją na tle pozostałych jednostek. Dzielenie populacji na warstwy jest wskazane w przypadku, gdy rozkład cech w badanej zbiorowości jest asymetryczny oraz populacja jest zróżnicowana ze względu na inne kryterium klasyfikacji, np. terytorium występowania czy też chronologię. W takim przypadku losowanie od razu jednostek indywidualnych może dać zniekształcony obraz badanego problemu, ponieważ jest prawdopodobne, że w przeważającej części wylosowane zostaną elementy nietypowe lub też żaden z nich nie wejdzie do próby. Losowanie warstwowe polega na doborze losowym prób z każdej warstwy z osobna, po ustaleniu, ile jednostek z każdej z nich zostanie wylosowanych, a przeprowadzane losowania w warstwach jest dowolne, może być indywidualne lub też grupowe ${ }^{34}$.

W przypadku losowania warstwowego możemy mówić o ograniczonym doborze próby, gdyż wylosowanie z danej warstwy wcześniej ustalonej liczby jednostek uniemożliwia wylosowanie pozostałych elementów na nią się składającej. O losowaniu nieograniczonym mówimy za to wtedy, gdy dobór jednostki czy pewnej liczby jednostek (nieprzekraczającej oczywiście zaplanowanej jej liczby dobranej do próby) nie wyklucza wylosowania żadnej z pozostałych jednostek populacji, o takim doborze mówimy w przypadku np. losowania prostego.

33 Tamże, s. 72.

34 W. Miszczak, W. Ostasiewicz, J. Wawrzynek, Projektowanie próby z elementami planowania eksperymentów, Wrocław 2008, s. 54-55. 
Losowaniem wieloetapowym nazwiemy losowanie wielostopniowe. Pierwszym etapem jego przeprowadzenia jest skonstruowanie grup jednostek, czyli jednostek losowania pierwszego stopnia, następnie losujemy pewną liczbę tych jednostek. Jednostki wylosowane dzielimy na kolejne jednostki (indywidualne lub zespołowe) i poddajemy je po raz kolejny losowaniu, który w tym przypadku nazwiemy losowaniem drugiego stopnia. Jeżeli pobieranie próby kończy się na dwóch losowaniach, to metodę nazwiemy losowaniem dwustopniowym, oczywiście stopni losowania może być więcej. Jeżeli jednostki dzielimy na grupy, na podstawie konkretnego kryterium, wtedy nasze losowanie wielostopniowe jest zarazem losowaniem warstwowym, dobór losowy niezależnych prób jest wtedy dokonywany w obrębie każdej warstwy ${ }^{35}$. Opis tak przeprowadzonego badania w dziedzinie archiwalnej możemy znaleźć w artykule Waldemara Chorążyczewskiego ${ }^{36}$. Proponuje on stosowanie metody reprezentacyjnej przy badaniu nowożytnych dokumentów królewskich, jednakże rozciąga zasięg przydatności tejże metody na dokumentację masową, wytwarzaną do czasów nam współczesnych. Chociaż autor omawia użycie tej metody na gruncie dyplomatyki, to możemy z łatwością przełożyć jego postulaty na grunt archiwalny. Po pierwsze dyplomatyka jest nauką pokrewną archiwistyce a próbkowanie względem dokumentacji masowej, może być przydatne do jej naukowego wartościowania. Jest to tzw. sampling archiwalny, który może ułatwić selekcję dokumentacji. Metoda reprezentacyjna została zaczerpnięta ze statystyki jako metoda gromadzenia danych, gdyż w stosunku do dokumentacji, narastającej lawinowo, nie jest możliwe przebadanie jej całości, czy nawet wybranej większej części, nawet po dokonaniu zawężenia przedmiotu badań - formalnie, rzeczowo czy chronologicznie. W takim właśnie przypadku najwłaściwszy byłby wybór pewnej części - próbki dokumentacji, będącej obiektem naszego badania, przy czym próbka ta musi być jak najbardziej reprezentacyjna dla całości.

Metoda ta nie polega jedynie na wytypowaniu jak najodpowiedniejszej ilości obiektów do badania, ale często również na ustaleniu, ile wynosi rzeczywista liczba wszystkich obiektów tworzących całość badanego przedmiotu. Z tym problemem właśnie zetknął się autor, próbując ustalić całkowitą

${ }^{35}$ M. Mróz, S. Sirko, dz. cyt., s. 73.

36 W. Chorążyczewski, Nowożytny dokument królewski. Możliwości badawcze, [w:] Polska kancelaria królewska czasów nowożytnych. Między wtadzą a spoteczeństwem. Materiaty konferencji naukowej, Torun 18 kwietnia 2002 roku, red. W. Chorążyczewski i W. Krawczuk, Toruń 2003, s. 27-48. 
ilość dokumentów wytworzonych w kancelarii królewskiej Zygmunta Starego. Zakładając, że zachowały się wszystkie dokumenty, których odbiorcą był Toruń i stany pruskie, obliczył stosunek tych materiałów, znajdujących się w archiwum toruńskim, do tych zarejestrowanych w księgach Metryki Koronnej, czyli 143:28; w ten sposób, znając liczbę wszystkich dokumentów w Metryce, których wystawcą był król, czyli 23450 dokumentów, z łatwością obliczył przewidywaną całość tejże dokumentacji (119763). Aby uniknąć zniekształceń wyników ostatecznych, wybór losowy próbki i jej badanie powinno odbywać się etapami. Autor proponuje, najpierw przeprowadzić losowanie dwustopniowe, a następnie dwufazowe, jest to pogląd odmienny od tego występującego w statystyce, gdzie przewiduje się wybór między badaniem wielostopniowym, a wielofazowym, bez łączenia ich. Dwustopniowość polega tu na losowaniu w pierwszej kolejności instytucji, przechowujących interesujące nas akta, następnie wśród wytypowanych jednostek organizacyjnych losujemy materiały, podlegające badaniu. Pamiętając, że próbka powinna być jak najliczniejsza, możemy w pierwszym losowaniu akt wytypować obszerniejszą część całości, by zbadać ją dwufazowo, najpierw ogólnie, a po drugim losowania, zawężającej krąg badanych obiektów, szczegółowo.

Chorążyczewski przyznaje, że użycie tej metody jest dopiero postulowane, dlatego jej poznanie wymaga od badaczy większego zgłębienia wiedzy statystycznej, aby wykluczyć pomyłki przy wybieraniu prób oraz poznać wszelkie możliwości zniekształcenia wyników badań, ponieważ metoda ta nigdy nie zagwarantuje pełnej zgodności z wynikami badań przeprowadzonych na całości materiałów. W przypadku dokumentacji masowej jest to prawdopodobnie najodpowiedniejsza metoda badania. Wprowadzenie metody reprezentacyjnej musi jednak wiązać się ze ściślejszą współpracą z naukami statystycznymi i matematycznymi, poznania literatury specjalistycznej, gdyż przy stosowaniu metod całkowicie różnych od tych dotychczas stosowanych bardzo łatwo popełnić błędy, zniekształcające wynik badania.

Kolejną metodą wybrania próby jest losowanie systematyczne, które polega na wyborze do próby spośród uporządkowanych jednostek losowania elementów populacji oddalonych od siebie o stałą wartość $k$, zwaną interwałem losowania, co szczegółowo opisuje R. Zasępa ${ }^{37}$.

Jednym z poważniejszych problemów, jak i zasadniczym zadaniem przed przystąpieniem do losowania, jest ustalenie liczebności próby, ponieważ bez

${ }^{37}$ R. Zasępa, dz. cyt., s. 223-229. 
znanej wielkości próby minimalnej nie można zastosować metody doboru. Problem tkwi w ustaleniu, jak liczna ma być próba, aby na podstawie wyników pomiaru możliwe było wyciągnięcie wniosków o badanej populacji, wniosków charakteryzujących się określoną dokładnością i stopniem pewności. Im większa liczebność próby, tym wyniki są bardziej precyzyjne, jednak wzrost liczebności próby zwiększa koszty badania. Z tego wniosek, że wielkość próby nie powinna być uzależniona od wielkości populacji. Przed określeniem minimalnej liczby elementów, mających wejść do próby, badacz powinien ustalić poziom precyzji, jakimi mają charakteryzować się wyniki badania, nie bez wpływu na to jest liczba podzbiorów, warstw, na jakie populacja generalna, w naszym przypadku zasób Archiwum Państwowego w Toruniu, zostanie podzielona ${ }^{38}$. Wielkości próby określane są na podstawie wzorów, wykorzystujących różne dane, w dalszej części pracy niektóre z nich zostaną opisane przy okazji ich użycia w badaniu praktycznym, związanym z wytypowaniem zespołów do badania efektywności informacyjnej archiwum.

\section{Metody STATYSTYCZNE}

Dwie powyżej opisane metody (reprezentacyjna i eksperyment) posłużyły do zgromadzenia danych, potrzebnych do oceny efektywności informacyjnej danego systemu wyszukiwawczego. Etapem końcowym będzie sformułowanie wniosków na podstawie zebranych danych. W przypadku, gdy zgromadzony materiał przedstawia się w postaci zestawień liczbowych, najodpowiedniejsze będzie przeprowadzenie analizy ilościowej, posiłkując się metodą statystyczną, pozwalającą obliczyć wskaźniki, określające efektywność wyszukiwania, co w konsekwencji prowadzi do jej bezpośredniej oceny. Nie można zapomnieć, że metoda statystyczna, pomimo dostarczenia bezpośrednich danych do analizy, pozostaje metodą gromadzenia, nie analizowania danych. Badanie statystyczne składa się z trzech podstawowych etapów: obserwacji (rejestracja jednostek należących do badanej społeczności, czyli gromadzenie danych), opisie statystycznym i analizie statystycznej. Na czynności wchodzące w skład etapu drugiego składa się przetwarzanie danych statystycznych, ale bez formułowania wniosków, poza tymi, które wynikają z samych danych. Analiza statystyczna w przypadku, gdy badamy jedynie próbę z badanej zbio-

${ }^{38}$ M. Mróz, S. Sirko, dz. cyt., s. 73-74. 
rowości, będzie wymagała wyprowadzenia uogólnień, wykraczających poza zebrane dane, w takim przypadku powinniśmy posiłkować się teorią prawdopodobieństwa. Po wyborze zmiennych, między którymi chcemy poznać łączące je relacje, i zebraniu danych, przeprowadzamy badania, których celem jest ustalenie współczynników współzależności dwóch lub większej liczby cech zmiennych, co może nas prowadzić, w toku dalszej analizy, do ustalenia przyczyn istniejących zależności ${ }^{39}$.

Jak pisze A. Burzyński, stosowanie metod statystycznych w naukach humanistycznych wymaga poszanowania stosunku statystki do nauk realnych (których przedmiotem badań jest świat rzeczywisty). W tym przypadku, prowadząc badanie, trzeba pamiętać o pierwszeństwie nauki przedmiotowej nad stosowaną metodą statystyczną, gdyż to konkretny problem badawczy wyznacza jej zastosowanie. Brak szczegółowego ustalenia problemu, który będzie poddany badaniu, brak wytyczenia jego zakresu, wraz z nieustalonymi ściśle stosowanymi pojęciami, może prowadzić do odstępstwa, skrzywienia badanej rzeczywistości w interpretacji wyników, gdyż wtedy wnioski będą odbiegały od zakresu dyscypliny naukowej, która metodą statystyczną się posłużyła ${ }^{40}$.

Podstawą wyprowadzonych wzorów na wszystkie wskaźniki, określające efektywność systemu, są wartości trzech rodzajów odpowiedzi, istniejących w archiwalnym procesie wyszukiwania. Dla przypomnienia są to: źródła trafnie wyszukane, źródła wyszukane i źródła odpowiadające pytaniu; dla ich scharakteryzowania posłuży poniższy schemat. Zarówno schemat ten, jak i poniższe wzory były opisywane przez Bohdana Ryszewskiego, jednak dla systematyzacji informacji w niniejszym artykule, a także wstępie do opisu przeprowadzonego badania, pozwalam sobie zamieścić niniejsze informacje ponownie.

39 J. Pieter, dz. cyt., s. 89-91.

40 A. Burzyński, dz. cyt., s. 141-142. 
Rysunek 2. Rodzaje odpowiedzi w procesie wyszukiwania

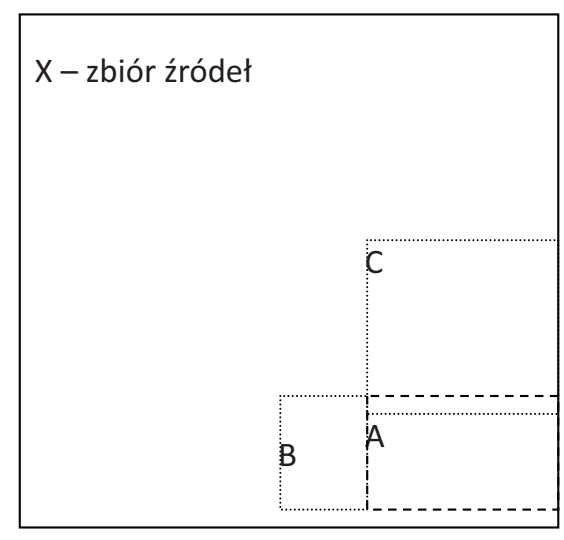

$$
\begin{aligned}
& \text { A - źródła trafnie wyszukane } \\
& \text { (relewantne w odpowiedzi) } \\
& \text { B-źródła wyszukane } \\
& \text { C-źródła odpowiadające pytaniu } \\
& \text { (relewantne w zbiorze) } \\
& \text { 1. B-A (źródła } \\
& \text { nieodpowiadające } \\
& \text { pytaniu, a wyszukane } \\
& \text { przez system) } \\
& \text { 2. C-A (źródła } \\
& \text { odpowiadające pytaniu, } \\
& \text { a niewyszukane } \\
& \text { przez system) }
\end{aligned}
$$

Źródło: B. Ryszewski, Problemy i metody badawcze archiwistyki, Toruń 1985, s. 136.

Liczbę poszczególnych odpowiedzi, czyli liczbę dokumentów wyszukanych lub nieustalamy w ramach przeprowadzonego eksperymentu. Dla zbadania efektywności najważniejsze jest ustalenie dwóch współczynników, o których była już mowa wcześniej, czyli o wskaźniku kompletności i dokładności. Wskaźnik kompletności (czułości) jest określany na podstawie wzoru:

$$
K=\frac{A}{C},
$$

który określa stosunek liczby dokumentów trafnie wyszukanych do liczby wszystkich dokumentów relewantnych w danym zbiorze. Wskaźnik trafności (dokładności) określany jest stosunkiem liczby dokumentów trafnie wyszukanych w danym zbiorze, do liczby wszystkich dokumentów wyszukanych przez system w odpowiedzi na dane pytanie. Wskaźnik wyraża się wzorem:

$$
T=\frac{A}{B},
$$

Odwrotnością współczynnika trafności jest współczynnik szumu, który skupia się na dokumentach niewłaściwie wyszukanych. Jest on określany przez stosunek liczby dokumentów wyszukanych niewłaściwie do liczby 
wszystkich dokumentów wyszukanych przez system w odpowiedzi na dane pytanie:

$$
S z=\frac{B-A}{B} .
$$

Kolejnym wskaźnikiem uzupełniającym, tym razem dla wskaźnika kompletności, jest wskaźnik strat (ciszy), czyli stosunek liczby dokumentów relewantnych niewyszukanych przez system do liczby dokumentów relewantnych w zbiorze, co obliczamy według wzoru:

$$
S t=\frac{C-A}{C} \text {. }
$$

Suma współczynników kompletności i ciszy równa jest zawsze jedności, $\mathrm{A}+\mathrm{E}=\mathrm{C}$, dlatego można się posługiwać tylko jednym z nich, podobnie rzecz się ma w przypadku współczynnika trafności i szumu.

B. Ryszewski uważa cztery powyższe wzory za najbardziej przydatne dla oceny efektywności informacyjnej, jednakże wymienia jeszcze inne, mające według niego znikome znaczenie. Wśród nich jest wskaźnik wyszukiwania informacji, który może być wartościowy w przypadku, gdy znamy dokładną zawartość dokumentów w danym zbiorze. Wyrażamy go przez stosunek liczby dokumentów relewantnych do liczby dokumentów wyszukanych przez system dla danej odpowiedzi; wyrażany za pomocą wzoru:

$$
W=\frac{C}{B} .
$$

Odwracając w powyższym wzorze licznik i mianownik, jesteśmy w stanie obliczyć współczynnik efektywności języka informacyjnego:

$$
E f .=\frac{B}{C} .
$$

Możemy jeszcze wyróżnić dwa wskaźniki: wyłączenia i odpowiedzi. Pierwszy z nich wyrażony jest za pomocą wzoru:

$$
W y \nmid .=\frac{X-B}{C} .
$$

Jest to stosunek liczby dokumentów niewyszukanych w danym zbiorze do liczby dokumentów odpowiadających pytaniu. Wskaźnik odpowiedzi okre- 
ślany jest stosunkiem liczby dokumentów wyszukanych do liczby dokumentów składających się na cały zbiór ${ }^{41}$ :

$$
O d p .=\frac{B}{X} .
$$

W wyniku przeprowadzonego eksperymentu i zebrania danych możemy zastosować wyżej omówione wzory, określające współczynniki efektywności informacyjnej. Dopiero po ich zastosowaniu możemy ocenić, na ile otrzymane wyniki działań matematycznych są przydatne do analizy systemu informacji archiwalnej.

\section{Program badania SYSTEMU INFORMaCJI ARCHIWALNeJ}

Trzonem przeprowadzonego badania była propozycja Bohdana Ryszewskiego zastosowania wzorów matematycznych dla obliczenia trafności i kompletności informacyjnej systemów wyszukiwawczych w archiwach oraz metoda eksperymentu, potrzebne do ustalenia danych dla obliczenia tych dwóch $\operatorname{cech}^{42}$.

Zapoznanie się z literaturą dotyczącą powyżej wymienionych metod pozwoliło na sporządzenie programu badania na nich bazującego. Pierwszym etapem pracy, zmierzającej do oceny systemu wyszukiwawczego, jest wytypowanie zespołów i wchodzących w ich skład jednostek archiwalnych, które mają zostać poddane badaniu. Skorzystałam z metody reprezentacyjnej, pomagającej ustalić liczbę obiektów, którą należy zbadać, a także w jaki sposób powinno się ją wybrać/wylosować. Należy podkreślić, że bez znajomości zasobu i systemu pomocy ewidencyjno-informacyjnych rozpoczęcie badania byłoby niemożliwe, niniejsza praca ocenia teraźniejszy - trzeci system informacyjny Archiwum Państwowego w Toruniu. Tematem tym zajmował się już wcześniej Waldemar Chorążyczewski, co pozwala na pominięcie zagadnienia i kierowanie do już istniejącej literatury, traktującej o tym temacie ${ }^{43}$.

41 M. Gołembiowski, dz. cyt., s. 87-91; B. Ryszewski, dz. cyt., s. 136-138.

42 B. Ryszewski, dz. cyt., s. 129-150.

43 W artykule W. Chorążyczewskiego znajdują się informacje o istniejącej literaturze na ten temat: W. Chorążyczewski, Akta i księgi wpisów w Archiwum Państwowym w Toruniu. Systemy informacyjne, [w:] Kancelarie okresu księgi wpisów w Prusach Królewskich. Materiaty sesji odbytej 20-21 listopada 1992 roku w Archiwum Państwowym w Toruniu, red. A. Tomczak, Warszawa 1994, s. 123-132. 
Etap drugi polega na badaniu wylosowanych jednostek archiwalnych przez badacza. Polega to na zapoznaniu się z treścią każdej jednostki, wszystkich zawartych w niej dokumentach i ich analizie. Praca ta powinna dawać pełny obraz treści, jaką zawierają wylosowane jednostki w danym zespole, tak pod względem rzeczowym, chronologicznym, terytorialnym, jak i zawierać informacje o postaci zewnętrznej materiałów. Nie jest możliwa pełna obiektywność na tym etapie, gdy badanie prowadzi jedna osoba, dlatego też w przypadku, gdy efektem końcowym badania jest ocena pomocy archiwalnych, badacz nie powinien mieć z nimi styczności lub ograniczyć ją do minimum w czasie zapoznawania się z jednostkami archiwalnymi. Znając zawartość informacyjną przeanalizowanego materiału, można ustalić przykładowy temat, a dla lepszej oceny pomocy archiwalnej dwa tematy odnoszące się do poszczególnych zespołów archiwalnych. W ten sposób badacz, nie znając środków ewidencyjno-informacyjnych, dysponuje wiedzą, w których jednostkach archiwalnych można odnaleźć informacje na dany temat.

Użytkownicy (osoby biorące udział w eksperymencie) mają za zadanie wyszukać informacje, które ich zdaniem odpowiadają na dane zapytanie, czyli zawierają informacje na temat wyznaczony wcześniej przez badacza. Osoby te nie znają treści archiwaliów, do dyspozycji mają jedynie pomoce ewidencyjno-informacyjne, sporządzone dla badanych wcześniej zespołów. Po zebraniu danych $\mathrm{z}$ analizowanej części zespołów, a także tych uzyskanych od użytkowników, można przy pomocy wzorów matematycznych ustalić wskaźniki: trafności, kompletności, szumu, strat, efektywności języka informacyjnego, wyłączenia i odpowiedzi. Na podstawie uzyskanych wyników spróbuję ocenić system informacji archiwalnej, przede wszystkim system wyszukiwawczy, a także wskazać błędy obniżające jego efektywność, co ma na celu ocenę przydatności wskaźników efektywności informacyjnej w badaniu archiwów.

\section{ZASTOSOWANIE METODY REPREZENTACYJNEJ DLA WYBORU PRÓB ZESPOŁÓW POTRZEBNYCH DO PRZEPROWADZENIA BADANIA}

Nie jest możliwa ocena systemu informacji archiwalnej danego archiwum przez zbadanie jego całego zasobu. Przebadanie kilkuset tysięcy jednostek archiwalnych jest fizycznie niemożliwe, wyjściem jest tu już wyżej wspomniana metoda reprezentacyjna, pozwalająca na wnioskowanie o całości na przykładzie wylosowanej z niej próby. Struktura zasobów archiwów państwowych 
wyznaczała wybór metody losowania. Wybór próby powinien zostać z góry zaplanowany i przemyślany. Nie ulega wątpliwości, że jednostką próby powinna być jednostka archiwalna, jednak specyficzna budowa zasobu archiwalnego, jego stopniowość, uniemożliwia w pierwszym losowaniu wybranie jednostki archiwalnej bez poprzedzającego go wyboru zespołów archiwalnych. W przypadku badania systemu informacji archiwalnej najbardziej zasadne wydaje się przeprowadzenie losowania dwustopniowego, w pierwszym etapie wybieramy zespoły archiwalne do badania, a w drugim jednostki archiwalne z wcześniej wylosowanych zespołów. Oczywiście w pierwszym doborze próbek losuje się z całej populacji generalnej, jaką jest tu zasób Archiwum Państwowego w Toruniu, liczącym w danym momencie (23 czerwca 2011 r.) 1777 zespołów, jest to losowanie zespołowe, w drugim etapie losuje się z całej populacji danego zespołu, a liczebność zespołów archiwalnych jest różna. W ostatnim losowania mówimy już o losowaniu indywidualnym, gdyż wytypowane zostały pojedyncze jednostki populacji (zespołu archiwalnego). W obu etapach zastosowano metodę bez zwracania, wylosowane jednostki nie uczestniczą w dalszym losowaniu, nie ma możliwości, że do badania wytypowany zostanie więcej niż jeden raz dany zespół czy jednostka archiwalna.

W tym miejscu badania powstaje pytanie, ile zespołów, a następnie jednostek archiwalnych należy wylosować, aby można mówić o reprezentatywności danej próby? Należy wypośrodkować liczebność zbioru z możliwym, włożonym w badanie nakładem pracy, nie zapominając o zamierzonym poziomie precyzji wyniku. W tym przypadku pomocne jest użycie wzoru na wielkość próby, trzeba podkreślić, że w literaturze statystycy podają bardzo wiele tego rodzaju wzorów, bazujących na różnych danych. Wybór metody matematycznej był w tym przypadku podyktowany stopniem umiejętności badacza w dziedzinie statystyki oraz charakterem prowadzonego badania, czyli możliwością zastosowania danego wzoru w dziedzinie archiwalnej.

Wzór zastosowany dla wytypowania ilości zespołów archiwalnych wygląda następująco:

$$
n=\frac{Z_{\alpha}^{2} \sigma^{2}}{e^{2}}
$$


gdzie $n$ oznacza wielkość próby, $\mathrm{Z}_{\alpha}$ - wielokrotność standardowego błędu średniej, odczytana z tablic dla $1-\alpha, \sigma$-odchylenie standardowe populacji, $e$ - ustalony wcześniej dopuszczalny błąd szacunku ${ }^{44}$.

Dla wyboru próbki jednostek archiwalnych z wcześniej wylosowanych zespołów przyjmujemy wzór ${ }^{45}$ :

$$
n=\frac{Z_{\alpha}^{2} p(1-p)}{e^{2}}
$$

gdzie jedynie $p$ - oszacowany wskaźnik proporcji wyróżnionej cechy w badanej populacji, nie pojawił się wcześniej.

Dlaczego właśnie te wzory? Podstawą do ich zastosowania jest ustalenie, czy interesująca nas zmienna jest ciągła, czy też dychotomiczna, można to też tłumaczyć jako badanie zmiennej w postaci średniej lub proporcji. O zmiennej ciągłej mówimy wtedy, gdy przedmiotem badania są mierzalne właściwości tego przedmiotu ${ }^{46}$, dlatego też wzór pierwszy stosujemy przy wyborze próbki zespołów, gdyż zmienna w tym przypadku, którą jest relewantność opisu zespołów do ich zawartości, w ogóle jest ciągła, można wyznaczyć wartość relewantności od 0 do 100\%.Przy wyprowadzaniu ilości jednostek do przebadania w danym zespole archiwalnym interesująca nas zmienna jest dychotomiczna - dwudzielna. W dalszym toku badania, przy indeksowaniu jednostek archiwalnych chcemy sprawdzić relewantność - w tym wypadku danej jednostki z opisem archiwalnym, co może przyjąć wartość 0 lub 1, nic pomiędzy, gdyż informacja może jedynie odpowiadać na dane zapotrzebowanie informacyjne lub nie.

Aby zastosować powyższe wzory, trzeba przeprowadzić badanie pilotażowe dla ustalenia wartości $\sigma$ oraz $p$, co ma nam przynieść wstępne rozeznanie w wartości badanej cechy, którą w tym przypadku jest relewantność informacji w jednostkach archiwalnych do opisu w pomocach ewidencyjno-

44 A. Mróz, S, Sirko, Elementy statystyki w badaniach naukowych, [w:] Metody, techniki i narzędzia badawcze oraz elementy statystyki stosowane w pracach magisterskich $i$ doktorskich, red. M. Cieślarczyk, Warszawa 2003, s. 74.

45 Szacowanie wielkości próby w badaniach ilościowych. [on-line] [Dostęp 5 lipca 2011 r.] Dostępny w World Wide Web: http://www.cem.pl/?a=pages\&id=53.

46 A. W. Maszke, Metodologiczne podstawy badań pedagogicznych, Rzeszów 2003, s. 68 . 
-informacyjnych. Badanie to polegało na zapytaniu ekspertów - wybrano pięciu naukowców, którzy przeprowadzali wcześniej kwerendy w archiwum toruńskim, o to, na ile procent według nich informacje zawarte w pomocach odzwierciedlają zawarte $\mathrm{w}$ jednostkach informacje, czyli na ile udało im się odnaleźć pożądaną informacje w zamówionych aktach. W charakterze ekspertów przebadani zostali: Sylwia Grochowina, Marcin Hlebionek, Wiesław Nowosad, Adam Szweda, Aleksander Smoliński. Oto udzielone przez nich odpowiedzi (liczba porządkowa odpowiada pomocy archiwalnej do jednego zespołu, który badali):

Trafność (odpowiedź zgodna z zapotrzebowaniem informacyjnym):

$1-70 \%$

$2-100 \%$

$3-100 \%$ (informacje wyszukiwane w Katalogu I, II, III)

$4-100 \%$ (informacje wyszukiwane w Katalogu I)

$5-75 \%$

$6-100 \%$

$7-100 \%$

$8-100 \%$

$9-100 \%$

$10-100 \%$

Dzięki tym danym można ustalić wartości następujących danych:

- $\sigma-11,476$ (odchylenie standardowe, a więc obliczony przedział różnicy między średnim wynikiem),

- p-wynosi 94,5\%, co daje 0,945 (proporcja, wyrażona w procentach, obliczona jako średnia arytmetyczna relewantności).

Wszelkie obliczenia dla pewności poprawności wyników zostały wykonane w arkuszu kalkulacyjnym Microsoft Excel. W tym momencie można przystąpić do właściwego obliczenia wartości próbek. Dla wzorów potrzebne są jeszcze dwie dane:

- $Z$, czyli przedział ufności, przyjmowany przez statystyków najczęściej na poziomie 95 lub 99\%, są one odczytywane z tablic dla $1-\alpha$. Im wyższy poziom ufności, tym większej próby wymaga, dlatego też w tym przypadku zostanie przyjęty poziom 95\%, co w statystyce przyjmuje się jako wartość $\mathrm{Z}=1,96^{47}$.

47 Szacowanie wielkości próby w badaniach ilościowych. [on-line] [Dostęp 5 lipca 2011 r.] Dostępny w World Wide Web: http://www.cem.pl/?a=pages\&id=53. 
- $e$ - jest dopuszczalnym błędem szacunku, podobnie jak przy wyprowadzaniu wartości sigmy, jest działaniem bardziej intuicyjnym niż ściśle matematycznym, w tym przypadku im założony zostanie większy błąd, tym mniejszej próby badanie wymaga, jednak trzeba to wypośrodkować, zbyt mała próba nie da wyniku reprezentacyjnego dla całej zbiorowości, gdyż błąd w obliczeniach jest zbyt duży. Wartość ta została dla obu wzorów wyprowadzona oddzielnie, tak aby wielkość próby nie przewyższyła możliwości badacza, a błąd szacunku był jak najmniejszy.

Ustalenie liczebności próby zespołów do badania:

$$
n=\frac{1,96^{2} \times 11,65476^{2}}{8^{2}}=8,153402 \approx 8
$$

Przy niższych błędach szacunku wartość $n$ wynosi:

- dla $e=5 \%$, otrzymujemy $\mathrm{n}=20,87271$

- $6 \%$, to $n=14,49494$

- dla 7\% n=10,64934

Kolejny wzór pozwala ustalić liczebność próby (jednostek) do zbadania w każdym zespole:

$$
n=\frac{1,96^{2} \times 94,5(1-94,5)}{5^{2}}=79,86686 \approx 80
$$

Zgodnie z powyższymi obliczeniami badaniu III systemu informacyjnego należy poddać 8 zespołów, a w każdym z nich przebadać 80 jednostek archiwalnych. W ten sposób odrzucone zostają na początku zespoły, które nie przekroczyły przyjętej granicy liczebności, jednak może być zasadne pominięcie tej reguły w przypadku wylosowania zespołów mniejszych o kilka czy kilkanaście jednostek. Dla badania pomocy informacyjno-ewidencyjnych przydatniejsze może okazać się zbadanie całego zespołu, dla którego dana pomoc została opracowana, nawet jeśli liczy on 60 jednostek, niż wybranie 80 jednostek, będącym znikomym procentem w zespole, liczącym ich kilkanaście tysięcy. Można pominąć sztywne trzymanie się wyniku matematycznego, gdyż końcowym rezultatem badania ma być analiza jakościowa, a nie ilościowa działania systemów. 
Losowanie próbek zespołów i jednostek archiwalnych może odbyć się w dwojaki sposób, pierwsza możliwość to zastosowanie tablic liczb losowych. Polega to na odczytaniu ciągu liczbowego od wybranego miejsca, czyli punktu przecięcia kolumny i wiersza z tablicy, nie sprawdza się to jednak w przypadku zasobu archiwum, gdyż tablice zawierają najczęściej liczby pięciocyfrowe, a liczebność zespołów archiwalnych może być większa. W przypadku badania zasobu Archiwum Państwowego w Toruniu, gdzie zbiorowość generalna, czyli całkowita liczba zespołów wynosi 1777 , odczytanie próby z tradycyjnej tabeli jest trudne. Oto przykład tabeli ${ }^{48}$ :

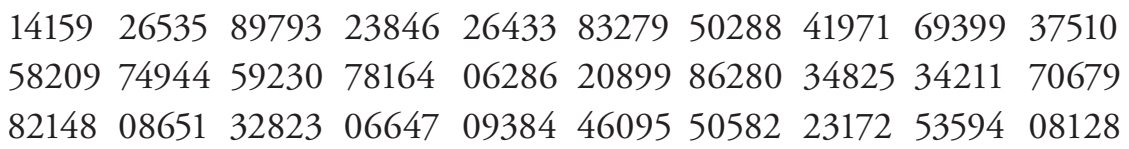

Zakładając, że jest to wylosowany przez nas ciąg liczbowy, odczytując z kolejnych wierszy cztery pierwsze cyfry liczb, gdyż nasza zbiorowość mieści się w tym przedziale (1777), wynikałoby, że z pierwszego wiersza odpowiada naszej próbie jedynie jedna liczba (14159, odczytana w tym przypadku jako 1415), z drugiego również jedna i z ostatniego wiersza cztery. Liczyć się należy również z okolicznością odrzucenia tych zespołów ze względu na małą liczebność danego zespołu czy braku jego ewidencji, dlatego użycie w tym przypadku tabeli liczb losowych okazuje się bardzo uciążliwe.

Alternatywą dla tego tradycyjnego i raczej przestarzałego sposobu jest wykorzystanie komputerowych generatorów liczb. Takie programy można odnaleźć w Internecie i właśnie ten sposób został w tym przypadku wykorzystany. Aplikacje te stanowią duże ułatwienie z kilku powodów: pozwalają ustalić przedział liczbowy, z którego pobierana jest próba (w przypadku typowania liczby zespołów poddanych badaniu wynosi on 1777, gdy w kolejnym losowaniu typować będziemy jednostki z danego zespołu, przedział liczbowy będzie wartością, stanowiącą liczbę wszystkich jednostek w tym zespole), pozwala ustalić, ile liczb ma zostać wylosowanych. W przypadku tego badania wykorzystano dwa internetowe generatory liczb losowych, pierwszy z nich dostępny na stronie tomaszwisniewski.com został wykorzystany do losowania próby

48 Tablica liczb losowych. [on-line] [Dostęp 23 kwietnia 2011 r.] Dostępny w World Wide Web: http://lgc.republika.pl/materialy/WWWopracowania/tab_los.pdf. 
zespołów ${ }^{49}$, jednakże program pozwalał na losowanie liczb jedynie w ograniczonym przedziale liczbowym, w związku z tym do losowania jednostek z poszczególnych zespołów wykorzystany został generator ze strony random.org ${ }^{50}$.

Dla wygenerowania próbki zespołów został ustalony przedział liczbowy o wartości od 1 do 1777, co odpowiada liczbie zespołów w zasobie archiwum toruńskiego, wylosowane liczby odpowiadają w tym przypadku numerom zespołów nadanym w bazie SEZAM. Oto liczby wylosowane:

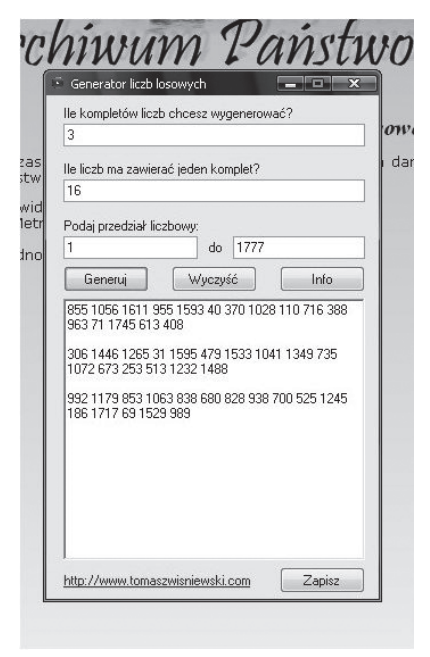

Aby skompletować 8 zespołów, potrzebnych do badania, czytając liczby po kolei wierszami, aż 24 zespoły zostały odrzucone. Najczęstszą przyczyną wykluczenia z badania była zbyt mała liczebność zespołów, brak ewidencji, a również problem w wylosowaniu jednostek do badania na podstawie dostępnych pomocy ewidencyjno-informacyjnych.

Do badania zostały przyjęte następujące zespoły:

1. 1593 Urząd Gminy w Ciechocinie, 1973-1990, 116 j.a., spis zdawczo-odbiorczy.

49 Generator liczb losowych. [on-line] [Dostęp 3 lipca 2011 r.] Dostępny w World Wide Web: http://tomaszwisniewski.com/generator-liczb-losowych/.

50 Generator losowych liczb całkowitych[on-line] [Dostęp 3 lipca 2011 r.] Dostępny w World Wide Web: http://www.random.org/integers/. 
2. 388 Powiatowa Rada Narodowa i Wydział Powiatowy w Wąbrzeźnie, 1945-1950, 90 j.a., inwentarz książkowy.

3. 1265 Akta Stanu Cywilnego parafii rzymskokatolickiej Ciechocin, 1670-1907, 89 j.a., inwentarz kartkowy przyjęty, inwentarz książkowy, spis zdawczo-odbiorczy.

4. 1041 Gminna Rada Narodowa w Biskupcu, 1973-1990, 248 j.a., spis zdawczo-odbiorczy

5. 735 Przedsiębiorstwo Nasiennictwa Ogrodniczego i Szkółkarstwa w Toruniu, 1945-1975, 106 j.a, spis zdawczo-odbiorczy .

6. 253 Kościół parafialny w Kaszczorku i filialny w Złotorii, 1779-1934, 164, inwentarz książkowy.

7. 1232 Urząd Stanu Cywilnego Szembruczek, 1874-1905, 139 j.a., inwentarz kartkowy przyjęty, inwentarz książkowy, spis zdawczo-odbiorczy.

8. 1488 Bydgoski Okręgowy Związek Piłki Ręcznej w Grudziądzu, 1956-1973, 64 j.a., inwentarz książkowy.

Zespoły odrzucone w losowaniu ze względu na zawieranie zbyt małej liczby jednostek archiwalnych:

1. 1611 Powiatowy Związek Cechów w Wąbrzeźnie, 1949, 1 j.a.

2. 40 Cech pantoflarzy z terenu miasta Torunia, 1642-1769, 3 j.a.

3. 370 Akta osób i rodzin - zbiór szczątków zespołów, 1701-1973, 21 j.a.

4. 1028 Urząd Gminy w Wąpielsku, 1973-1990, 16 j.a.

5. 110 Akta gminy Kozibór, pow. Toruński, 1639-1833 [1932-1939]

6. 716 Akta notariusza Antoniego Turczyna z Torunia, 1931-1933, 5 j.a.

7. 71 Bractwo religijne kaletników, rękawiczników, kapeluszników i rymarzy z terenu miasta Torunia, 1366-1913, 29 j.a.

8. 1745 Prokuratura Miasta i Powiatu Toruńskiego w Toruniu, [1949] 1950-1957, 41 j.a.

9. 613 Akta notariusza Józefa Reitera z Brodnicy, 1929-1933, 9 j.a.

10. 408 Gminna Rada Narodowa w Podwiesku, pow. Chełmiński, 1945$-1953,48$ j.a.

11. 306 Towarzystwo Miłośników Torunia, 1842-1923, 26 j.a.

12. 31 Cech łagiewników z terenu miasta Torunia, 1500-1880, 11 j.a.

13. 1595 Książnica Miejska w Toruniu, 1923-1939, 42 j.a.

14. 479 Zakłady Jajczarsko-Drobiarskie w Toruniu, 1948-1956, 10 j.a. 
15. 1533 Akta notariusza Eugeniusza Kolasińskiego w Grudziądzu, 1934$-1945,20$ j.a.

16. 1349 Prokuratura Sądu Okręgowego w Toruniu, 1920-1939, 3 j.a.

17. 1072 Przedsiębiorstwo handlowe kupca Samuela Edwardsa, 1636$-1660,23$ j.a.

18. 673 Ewangelicka Gmina Wyznaniowa w Kokocku, 1934-1938, 1 j.a.

19. 513 Rolniczy Zespół Spółdzielczy „Zwycięstwo” w Książkach, pow. Wąbrzeski, 1950-1957, 11 j.a.

Zespoły odrzucone ze względu na zbyt małą liczbę jednostek archiwalnych, powstałych przed rokiem 1981, cezur audostępniania - 30 lat:

1. 963 Miejska Rada Narodowa w Wąbrzeźnie, [1959] 1973-1986, 111 j.a., spis zdawczo-odbiorczy.

Zespoły odrzucone ze względu na brak ewidencji:

1. 1056 Przedsiębiorstwo Państwowe Pracownie Konserwacji Zabytków, Oddział w Toruniu, 1952-1991, 138565 j.a., bez ewidencji, inne pomoce, inwentarz książkowy, spis zdawczo-odbiorczy.

2. 1446 Prezydium Miejskiej Rady Narodowej w Łasinie, 1950-1972, 547 j.a., bez ewidencji, spis zdawczo-odbiorczy.

Zespoły odrzucone ze względu na brak możliwości wylosowania jednostek na podstawie pomocy ewidencyjno-informacyjnej:

1. 855 Pracownie Sztuk Plastycznych, Oddział w Toruniu, 1966-1977, 404 j.a., spis zdawczo-odbiorczy - zespół zaopatrzony w spis zdawczo-odbiorczy, na zespół składają się 404 plany i projekty zgrupowane w 13 rulonach i to one posiadają osobne pozycje w spisie. Nie można losować pojedynczych planów.

Zespoły przemieszczone do innych archiwów:

1. 955 


\section{PrZeProwAdZeNIE EKSPERYMENTU ORAZ OBLICZENIE WSPÓŁCZYNNIKÓW EFEKTYWNOŚCI INFORMACYJNEJ}

Kolejnym etapem badania jest losowanie jednostek archiwalnych z zespołu indywidualnie, gdyż każdy dobór próby wymaga ustawienia innego przedziału liczbowego, z którego liczby są losowane. Spowodowane jest to specyfiką zasobu archiwalnego, zespoły posiadają różną liczbę jednostek archiwalnych. Wylosowane liczby odpowiadają sygnaturom w inwentarzach archiwalnych lub też liczbom porząakowym, nadanym jednostkom według spisów zdawczo-odbiorczych. Po wylosowaniu jednostek można przystąpić do ich badania, czyli zamówienia do pracowni naukowej na podstawie pomocy informacyjno-ewidencyjnych, oraz zapoznaniu się z zawartością informacyjną danej jednostki. Pracy tej towarzyszy analiza treści jednostki, wypisywanie haseł charakteryzujących zawartość czy też szerszych opisów, co jest pomocne w ustalaniu tematów, dotyczących zespołu, na podstawie których będzie badana relewantność informacji w archiwaliach z pomocą ewidencyjno-informacyjną.

Każdy zespół po zbadaniu został zaopatrzony w dwa tematy, chyba że informacje w materiałach były jednorodne i w takim przypadku ustalono jeden temat. Zabieg ten ma na celu wyciągnięcie bardziej obiektywnych wniosków, obliczenie wskaźników efektywności dla dwóch tematów, pozwala na badanie porównawcze, mające na celu postawienie jak najwnikliwszych wniosków o danej pomocy archiwalnej. Podobnie rzecz się ma z wyznaczeniem liczby osób, które powinny brać udział w eksperymencie. Zadaniem osób poddanych badaniu jest wskazanie jednostek, mając do dyspozycji jedynie inwentarz czy spis, w których są zawarte informacje, odnoszące się do danego tematu. Według autora liczbą optymalną jest 10 osób, daje to już konkretny pogląd na badanie i dostarcza wystarczającej ilości danych. W przypadku dwóch wylosowanych zespołów, których inwentarze archiwalne zostały stworzone w całości lub przeważającej części w języku niemieckim, liczba osób biorących udział w eksperymencie została zniwelowana do 5, gdyż język ten stanowił dla większości dużą barierę w wyznaczeniu jednostek archiwalnych. Osoby, biorące udział w badaniu, nie zostały przypadkowo wybrane do eksperymentu, ważne jest podkreślenie, że w badaniu systemu informacji archiwalnej główny nacisk kładzie się na ocenę pomocy, a nie użytkowników. Dlatego też była to grupa jednorodna, składająca się ze studentów archiwistyki, pracownika naukowego i studenta historii. Wybór ten został podyktowany 


\section{Monika CoŁbecka}

przygotowaniem archiwalnym tych osób, znajomością zasad wyszukiwania informacji w archiwum, co zaoszczędziło badaczowi problemów ze wstępnym szkoleniem osób, które takiego doświadczenia nie posiadałyby.

Dla przypomnienia: wyniki eksperymentu mają na celu dostarczenie danych, potrzebnych do obliczenia następujących współczynników efektywności informacyjnej:

\begin{tabular}{|l|c|}
\hline Wskaźnik kompletności & $K=\frac{A}{C}$, \\
\hline Wskaźnik trafności & $T=\frac{A}{B}$, \\
\hline Wskaźnik szumu & $S z=\frac{B-A}{B}$ \\
\hline Wskaźnik strat (ciszy) & $S t=\frac{C-A}{C}$ \\
\hline Wskaźnik wyszukiwania informacji & $W=\frac{C}{B}$ \\
\hline Wskaźnik efektywności języka informacyjnego & $E f .=\frac{B}{C}$ \\
\hline Wskaźnik wyłączenia & Wył. $=\frac{X-B}{C}$ \\
\hline Wskaźnik odpowiedzi & Odp. $=\frac{B}{X}$ \\
\hline
\end{tabular}

Jak widać, aby dokonać obliczeń, wymagana jest znajomość wartości dla czterech niewiadomych:

- A - Liczba dokumentów trafnie wyszukanych

- B - Liczba wszystkich dokumentów wyszukanych przez system

- C - Liczba wszystkich relewantnych dokumentów w danym przypadku

- X - Zbiór źródeł

Stan idealny to taki, gdy po podstawieniu danych do wzoru, wskaźniki trafności oraz kompletności mają wartość 1 , a wskaźniki szumu i straty 0 . Wcześniej była już mowa o tym, że wskaźnik kompletności i strat oraz para: trafność - szum, uzupełniają się, czyli zawsze suma każdej z wymienionych par musi dać wartość 1, co oznacza, że po obliczeniu kompletności znamy od razu wskaźnik strat, podobnie ma się rzecz z drugim omawianym wskaźnikiem. 
Pozostałe wskaźniki, o czym pisał już B. Ryszewskii ${ }^{51}$, mają znikomą wartość przy badaniu efektywności informacyjnej w archiwach, trudno przełożyć wyniki na wnioski. Wskaźników odpowiedzi oraz wyłączenia nie da się przełożyć na dziedzinę archiwalną, ponieważ obiektem ich badania jest całość jednostek wyszukanych lub niewyszukanych przez system, bez podziału na te relewantne i nierelewantne. Stosunek wszystkich jednostek niewyszukanych do całości zbioru jest nieważny, gdyż nie jest ważne, ile liczy dany zespół, czy ile jednostek ogółem można wydać na zapytanie do systemu, ważne jest, aby materiały wydane były zgodne z zapytaniem. Można jedynie poprawić informację o jednostkach, zawartą w źródłach pochodnych, samych jednostek nie można poprawić, nie może większa ich liczba nieść informacji na dany temat. Nieważna jest ilość informacji, zawartych w materiałach archiwalnych, a możliwość wydobycia tej już istniejącej.

Podobnie rzecz się ma ze wskaźnikiem wyszukiwania oraz efektywności języka informacyjnego, w których pod uwagę brane są dwie dane: liczba wszystkich relewantnych jednostek w danym zespole $-C$ i liczba wszystkich dokumentów wyszukanych przez system $-B$. W teorii próba zbadania, na ile system jest zdolny do odpowiedzi na dane pytanie, czy jest przystosowany do wyszukiwania, zdaje się całkiem zasadna. Jednak na ile wynik jest zgodny z rzeczywistością, gdy porównujemy przykładowo system, który wydał tylko i wyłącznie jednostki relewantne, a taki, który wydał jedynie dokumenty nierelewantne? Różnica jakościowa wyniku (o ile mamy taką samą liczbę jednostek odpowiadających pytaniu $-C$, wartości podstawiane do wzoru są te same) jest diametralna, analiza tych wskaźników nie daje żadnych logicznych wniosków, nie można ich interpretować, dlatego autor odstępuje od analizy wyników czterech omówionych wskaźników, jednak dla potwierdzenia postawionych tez zostały one obliczone dla wszystkich badanych zespołów.

Poniżej została zamieszczona charakterystyka badania każdego z zespołów wraz z wynikami eksperymentu.

\section{Powiatowa Rada Narodowa i Wydział Powiatowy w Wąbrzeźnie, 1945-1950}

Zespół ten liczy 90 jednostek archiwalnych i zaopatrzony jest w inwentarz książkowy, zgodnie z wcześniejszym ustaleniem wielkości próby wylosowano z niego 80 jednostek mających zostać zbadanymi. Po zapoznaniu się z treścią

51 B. Ryszewski, dz. cyt., s. 137-138. 


\section{Monika CoŁbecka}

wszystkich materiałów i zauważeniu spraw, które się w nich przewijały, a które mogą zostać ujęte w tematy, wybrano dwa z nich:

a) Służba zdrowia na terenie powiatu wąbrzeskiego

Jednostki, które zawierają informacje do tematu: 1, 2, 3, 14, 15, 28, $46,47,48,49,50,51,52,53,55,56,58,59,61,63,64,65,66,67,73$, $74,75,76,77,78,79,80,81,82,83,84,85$

- Łączna liczba jednostek odpowiadających pytaniu: 37

Wartości stałe:

$\mathrm{X}=80$

$\mathrm{C}=37$

Poproszono 10 osób o przejrzenie inwentarza zespołu i wytypowanie jednostek archiwalnych, w których znajdują się, ich zdaniem, materiały do podanego tematu. Po dokonaniu niezbędnych obliczeń uzyskano następujący wynik:

\begin{tabular}{|c|c|c|c|c|c|c|c|c|c|c|}
\hline $\begin{array}{l}\text { Dane/ } \\
\text { /osoby }\end{array}$ & 1 & 2 & 3 & 4 & 5 & 6 & 7 & 8 & 9 & 10 \\
\hline A & 19 & 9 & 11 & 10 & 13 & 15 & 15 & 13 & 14 & 15 \\
\hline B & 22 & 9 & 11 & 11 & 13 & 16 & 15 & 13 & 14 & 15 \\
\hline \multicolumn{11}{|c|}{ Wskaźniki } \\
\hline $\mathrm{K}$ & 0,51 & 0,24 & 0,3 & 0,27 & 0,35 & 0,41 & 0,41 & 0,35 & 0,38 & 0,41 \\
\hline $\mathrm{T}$ & 0,86 & 1 & 1 & 0,91 & 1 & 0,94 & 1 & 1 & 1 & 1 \\
\hline$S_{z}$ & 0,14 & 0 & 0 & 0,09 & 0 & 0,06 & 0 & 0 & 0 & 0 \\
\hline St & 0,49 & 0,76 & 0,7 & 0,73 & 0,65 & 0,59 & 0,59 & 0,65 & 0,62 & 0,59 \\
\hline W & 1,68 & 4,11 & 3,36 & 3,36 & 2,85 & 2,31 & 2,47 & 2,85 & 2,64 & 2,47 \\
\hline Odp. & 0,28 & 0,11 & 0,14 & 0,14 & 0,16 & 0,2 & 0,19 & 0,16 & 0,18 & 0,19 \\
\hline Wył. & 1,57 & 1,92 & 1,86 & 1,86 & 1,81 & 1,73 & 1,76 & 1,81 & 1,78 & 1,76 \\
\hline Ef. & 0,6 & 0,24 & 0,3 & 0,3 & 0,35 & 0,43 & 0,41 & 0,35 & 0,38 & 0,41 \\
\hline
\end{tabular}

Średnia dla wszystkich współczynników:

$\mathrm{K}=0,322, \mathrm{~T}=0,971, \mathrm{Sz}=0,029, \mathrm{St}=0,637$

$\mathrm{W}=2,81, \mathrm{Odp} .=0,175$, Wył=1,785, Ef.=0,377 
b) Walka $\mathrm{z}$ analfabetyzmem $\mathrm{w}$ powiecie wąbrzeskim

- Jednostki, które zawierają informacje do tematu 4, 14, 15, 18, 21, 30,31

- Łączna liczba jednostek odpowiadających pytaniu: 7

Wartości stałe:

$\mathrm{X}=80$

$\mathrm{C}=7$

\begin{tabular}{|c|c|c|c|c|c|c|c|c|c|c|}
\hline $\begin{array}{l}\text { Dane/ } \\
\text { /osoby }\end{array}$ & 1 & 2 & 3 & 4 & 5 & 6 & 7 & 8 & 9 & 10 \\
\hline A & 7 & 4 & 4 & 3 & 1 & 7 & 3 & 1 & 1 & 2 \\
\hline B & 19 & 4 & 4 & 4 & 3 & 8 & 6 & 1 & 1 & 6 \\
\hline \multicolumn{11}{|c|}{ Wskaźniki } \\
\hline $\mathrm{K}$ & 1 & 0,57 & 0,57 & 0,43 & 0,14 & 1 & 0,43 & 0,14 & 0,14 & 0,28 \\
\hline $\mathrm{T}$ & 0,37 & 1 & 1 & 0,75 & 0,34 & 0,86 & 0,5 & 1 & 1 & 0,34 \\
\hline $\mathrm{Sz}$ & 0,63 & 0 & 0 & 0,25 & 0,66 & 1,14 & 0,5 & 0 & 0 & 0,66 \\
\hline St & 0 & 0,43 & 0,43 & 0,57 & 0,86 & 0 & 0,57 & 0,86 & 0,86 & 0,72 \\
\hline W & 0,37 & 1,75 & 1,75 & 1,75 & 2,34 & 0,86 & 1,17 & 7 & 7 & 1,17 \\
\hline Odp. & 0,23 & 0,05 & 0,05 & 0,05 & 0,04 & 0,1 & 0,08 & 0,01 & 0,01 & 0,08 \\
\hline Wyt. & 8,71 & 10,86 & 10,86 & 10,86 & 11 & 10,29 & 10,57 & 11,29 & 11,29 & 10,57 \\
\hline Ef. & 2,71 & 0,57 & 0,57 & 0,57 & 0,42 & 1,14 & 0,86 & 0,14 & 0,14 & 0,86 \\
\hline
\end{tabular}

Średnia dla wszystkich współczynników:

$\mathrm{K}=0,47, \mathrm{~T}=0,716, \mathrm{Sz}=0,284, \mathrm{St}=0,53$

$\mathrm{W}=2,516$, Odp. $=0,07, \mathrm{Wy}_{\mathrm{y}}=10,63$, Ef. $=0,798$

W przypadku badanego zespołu współczynnik kompletności jest dość niski, na równym poziomie dla obu tematów. Co ważne, trafność przy tym jest dość wysoka, co wskazuje na to, że osoby zamawiające nie myliły się w swych wyborach, dodając do tego raczej małe różnice w wynikach dla wskaźnika kompletności u poszczególnych osób, można wnioskować o tym, że problem $\mathrm{w}$ procesie wyszukiwania tkwi w pomocy archiwalnej. Wskaźnik szumu, w odróżnieniu od kompletności, która wskazuje na jednostki relewantne, dobrze opisane przez pomoc archiwalną, wykazuje dokumenty nierelewantne, a wskazane przez system wyszukiwawczy. Współczynnik ten wskazał jednostki źle opisane, odpowiadające na niedotyczące je pytanie. 


\section{Gminna Rada Narodowa w Biskupcu, 1973-1990}

Ze względu na ramy chronologiczne zespołu, w pierwszym etapie badania został on okrojony o jednostki wytworzone po roku 1981; liczebność spadła z 248 do 169 jednostek archiwalnych i dopiero wtedy można było przystąpić do losowania przyjętej liczby. Badanie tego zespołu okazało się bardzo skomplikowane; powód: wytypowane, a następnie zamówione na podstawie spisu zdawczo-odbiorczego jednostki nie istnieją w magazynach archiwum. W takiej sytuacji badacz zdecydował się na częściowe pominięcie losowania w ten sposób, że do jednostek wytypowanych, które zostały mu udostępnione, dodał potrzebną mu liczbę z tych, które są przechowywane w archiwum. Czynność ta polegała na zamawianiu pominiętych w losowaniu jednostek zgodnie z kolejnością w spisie, aż do otrzymania pożądanej liczby materiałów. W toku badania zostały ustalone poniższe tematy:

a) Rozwój rolnictwa na terenie gminy Biskupiec

- Jednostki zawierające informacje do tematu: 1, 2, 3, 4, 5, 8, 9, 11, $12,16,17,18,19,24,26,29,33,35,36,39,42,45,49,52,53,60$, $61,117,121,133,145,155,156,159$

- Łączna liczba jednostek odpowiadających pytaniu: 34

Wartości stałe:

$\mathrm{X}=80$

$\mathrm{C}=34$

\begin{tabular}{|c|c|c|c|c|c|c|c|c|c|c|}
\hline $\begin{array}{l}\text { Dane/ } \\
\text { /osoby }\end{array}$ & 1 & 2 & 3 & 4 & 5 & 6 & 7 & 8 & 9 & 10 \\
\hline A & 9 & 7 & 9 & 7 & 4 & 7 & 5 & 5 & 6 & 6 \\
\hline $\mathrm{B}$ & 13 & 8 & 17 & 11 & 4 & 10 & 8 & 7 & 7 & 10 \\
\hline \multicolumn{11}{|c|}{ Wskaźniki } \\
\hline $\mathrm{K}$ & 0,26 & 0,2 & 0,26 & 0,2 & 0,18 & 0,2 & 0,15 & 0,15 & 0,18 & 0,18 \\
\hline $\mathrm{T}$ & 0,7 & 0,9 & 0,53 & 0,64 & 1 & 0,7 & 0,63 & 0,71 & 0,86 & 0,6 \\
\hline $\mathrm{Sz}$ & 0,3 & 0,1 & 0,47 & 0,36 & 0 & 0,3 & 0,36 & 0,29 & 0,14 & 0,4 \\
\hline St & 0,74 & 0,8 & 0,74 & 0,8 & 0,82 & 0,8 & 0,85 & 0,85 & 0,82 & 0,82 \\
\hline W & 2,62 & 4,25 & 2 & 3.1 & 8,5 & 3,4 & 4,25 & 4,86 & 4,86 & 3,4 \\
\hline Odp. & 0,16 & 0,1 & 0,21 & 0,14 & 0,05 & 0,13 & 0,1 & 0,09 & 0,09 & 0,13 \\
\hline Wył. & 1,97 & 2,12 & 1,85 & 2,03 & 2,24 & 2,06 & 2,12 & 2,71 & 2,71 & 2,06 \\
\hline Ef. & 0,38 & 0,24 & 0,5 & 0,32 & 0,12 & 0,29 & 0,24 & 0,21 & 0,21 & 0,29 \\
\hline
\end{tabular}


Średnia dla wszystkich współczynników:

$\mathrm{K}=0,196, \mathrm{~T}=0,727, \mathrm{Sz}=0,272, \mathrm{St}=0,804$

$\mathrm{W}=4,124, \mathrm{Odp} .=0,201, \mathrm{Wy}=2,187, \mathrm{Ef} .=0,28$

b) Działalność Gminnej Spółdzielni „Samopomoc Chłopska” na terenie gminy

- Jednostki zawierające informacje do tematu: 2, 3, 4, 5, 9, 10, 13, 14, $18,19,24,25,26,35,36,37,53,54,56,60,61,114,121,143,149$, $150,152,153,159$

- Łączna liczba jednostek odpowiadających pytaniu: 29

Wartości stałe:

$\mathrm{X}=80$

$\mathrm{C}=29$

\begin{tabular}{|c|c|c|c|c|c|c|c|c|c|c|}
\hline $\begin{array}{l}\text { Dane/ } \\
\text { losoby }\end{array}$ & 1 & 2 & 3 & 4 & 5 & 6 & 7 & 8 & 9 & 10 \\
\hline A & 12 & 1 & 3 & 0 & 0 & 0 & 0 & 3 & 0 & 10 \\
\hline B & 31 & 2 & 6 & 0 & 0 & 0 & 0 & 9 & 0 & 25 \\
\hline \multicolumn{11}{|c|}{ Wskaźniki } \\
\hline $\mathrm{K}$ & 0,41 & 0,03 & 0,1 & 0 & 0 & 0 & 0 & 0,1 & 0 & 0,34 \\
\hline $\mathrm{T}$ & 0,39 & 0,5 & 0,5 & 0 & 0 & 0 & 0 & 0,33 & 0 & 0,4 \\
\hline $\mathrm{Sz}$ & 0,61 & 0,5 & 0,5 & 1 & 1 & 1 & 1 & 0,67 & 1 & 0,6 \\
\hline St & 0,59 & 0,97 & 0,9 & 1 & 1 & 1 & 1 & 0,9 & 1 & 0,66 \\
\hline W & 0,93 & 14,5 & 4,83 & $\neq$ & $\neq$ & $\neq$ & $\neq$ & 3,22 & $\neq$ & 1,16 \\
\hline Odp. & 0,38 & 0,03 & 0,08 & 0 & 0 & 0 & 0 & 0,11 & 0 & 0,31 \\
\hline Wył. & 1,69 & 2,69 & 2,55 & 2,76 & 2,76 & 2,76 & 2,76 & 2,45 & 2,76 & 1,9 \\
\hline Ef. & 1,07 & 0,07 & 0,21 & 0 & 0 & 0 & 0 & 0,31 & 0 & 0,86 \\
\hline
\end{tabular}

Średnia dla wszystkich współczynników:

$\mathrm{K}=0,098, \mathrm{~T}=0,212, \mathrm{Sz}=0,788, \mathrm{St}=0,902$

$\mathrm{W}=2,464, \mathrm{Odp} .=0,091, \mathrm{Wy}=2,508, \mathrm{Ef} .=0,252$

Wartość wskaźnika kompletności w obu przypadkach jest niska, zwłaszcza w drugim jest wręcz znikoma, aż połowa z osób biorących udział w badaniu stwierdziła, że w danym zespole nie ma żadnych informacji, która mo- 
głaby dotyczyć Gminnej Spółdzielni „Samopomoc Chłopska”, czy też nie potrafili jej, na podstawie spisu zdawczo-odbiorczego, odnaleźć. Pozostałe osoby albo typowały bardzo wiele jednostek i w ten sposób trafiały na informacje, albo typowały niewiele, trafiając. Może to świadczyć o tym, że dla kilku jednostek relewantnych dla danego pytania opis został sporządzony poprawnie. Jednak wskaźnik straty jednoznacznie wskazuje, że większość odpowiednich dla tego jednostek nie została przez system wytypowana. Dla pierwszego tematu wskaźnik kompletności jest nieznacznie wyższy, za to trafność bardzo wysoka, oznacza to, że osoby typowały niewiele jednostek, ale na ogół dobrze. Uogólniając wnioski na cały zespół - tylko nieliczne jednostki są opisane prawidłowo - jednoznacznie wskazując na ich treść. Dodatkową przeszkodą w odnalezieniu odpowiedzi jest to, że nawet jeśli użytkownik wytypuje jednostkę, w której interesująca go informacja może się znajdować, może się okazać, że danej jednostki nie ma w archiwum.

\section{Przedsiębiorstwo Nasiennictwa Ogrodniczego i Szkółkarstwa w To- runiu, 1946-1975}

Jest to zespół zaopatrzony jedynie w spis zdawczo-odbiorczy i to na jego podstawie odbywa się udostępnianie materiałów użytkownikom. Jak się okazuje, w tym przypadku jest to czynność bardzo trudna, ponieważ zamawiając zgodnie z liczbą pojedynczą, nie dostaniemy pozycji, którą zamówiliśmy, teczki zostały przejęte do archiwum, źle je ponumerowano. Jedyną wskazówką dla poprawnego zamówienia jest znak teczki, czyli rubryka nr 2 w spisie, albo też, jak zrobiła to autorka, zamówienie całego zespołu i już w pracowni naukowej wyszukiwanie właściwych jednostek archiwalnych. Losowanie odbyło się spośród 106 jednostek, czyli badaniem objęte było ponad 3/4 zespołu, ustalono do niego poniższe tematy:

a) Zatrudnienie w Przedsiębiorstwie Nasiennictwa Ogrodniczego i Szkółkarstwa w Toruniu

- Jednostki zawierające informacje do tematu: 3, 6, 8, 10, 12, 13, 16, $18,20,21,23,24,27,28,29,30,32,34,35,36,37,40,44,46,47$, $48,49,51,53,54,55,57,63,65,72,82,87,88,91,92,93,95,97$, 99, 100, 101, 102

- Łączna liczba jednostek odpowiadających pytaniu: 47

Wartości stałe:

$\mathrm{X}=80$

$\mathrm{C}=47$ 


\begin{tabular}{|c|c|c|c|c|c|c|c|c|c|c|}
\hline $\begin{array}{l}\text { Dane/ } \\
\text { /osoby }\end{array}$ & 1 & 2 & 3 & 4 & 5 & 6 & 7 & 8 & 9 & 10 \\
\hline A & 6 & 6 & 10 & 2 & 11 & 3 & 5 & 7 & 26 & 7 \\
\hline B & 11 & 6 & 12 & 2 & 13 & 3 & 5 & 8 & 42 & 7 \\
\hline \multicolumn{11}{|c|}{ Wskaźniki } \\
\hline K & 0,13 & 0,13 & 0,21 & 0,04 & 0,23 & 0,06 & 0,11 & 0,15 & 0,55 & 0,15 \\
\hline $\mathrm{T}$ & 0,55 & 1 & 0,83 & 1 & 0,85 & 1 & 1 & 0,88 & 0,62 & 1 \\
\hline$S_{z}$ & 0,45 & 0 & 0,17 & 0 & 0,15 & 0 & 0 & 0,12 & 0,38 & 0 \\
\hline $\mathrm{St}$ & 0,87 & 0,87 & 0,79 & 0,96 & 0,77 & 0,94 & 0,89 & 0,85 & 0,45 & 0,85 \\
\hline W & 4,27 & 7,83 & 3,92 & 23,5 & 3,62 & 15,67 & 9,4 & 5,88 & 1,12 & 6,71 \\
\hline Odp. & 0,14 & 0,08 & 0,15 & 0,03 & 0,16 & 0,04 & 0,06 & 0,1 & 0,525 & 0,09 \\
\hline Wył. & 1,49 & 1,57 & 1,45 & 1,66 & 1,43 & 1,63 & 1,6 & 1,53 & 0,81 & 1,55 \\
\hline Ef. & 0,23 & 0,13 & 0,26 & 0,04 & 0,28 & 0,06 & 0,11 & 0,17 & 0,89 & 0,14 \\
\hline
\end{tabular}

Średnia dla wszystkich współczynników:

$\mathrm{K}=0,176, \mathrm{~T}=0,873, \mathrm{Sz}=0,127, \mathrm{St}=0,824$

$\mathrm{W}=8,192, \mathrm{Odp} .=0,14, \mathrm{Wy}$ =1,472, Ef. $=0,231$

b) Skup produktów rolnych

- Jednostki zawierające informacje do tematu: 1, 2, 3, 4, 6, 7, 8, 10, $12,13,20,21,23,24,32,34,36,37,40,43,44,46,47,48,50,52$, $56,57,58,59,60,64,66,69,72,84,93,95,96,97,99,100,101$, 102

- Łączna liczba jednostek odpowiadających pytaniu: 44 Wartości stałe:

$\mathrm{X}=80$

$\mathrm{C}=44$

\begin{tabular}{|c|c|c|c|c|c|c|c|c|c|c|}
\hline $\begin{array}{l}\text { Dane/ } \\
\text { losoby }\end{array}$ & 1 & 2 & 3 & 4 & 5 & 6 & 7 & 8 & 9 & 10 \\
\hline A & 14 & 2 & 1 & 2 & 3 & 5 & 5 & 18 & 14 & 26 \\
\hline B & 16 & 3 & 1 & 2 & 3 & 7 & 5 & 28 & 35 & 39 \\
\hline \multicolumn{11}{|c|}{ Wskaźniki } \\
\hline K & 0,32 & 0,05 & 0,02 & 0,05 & 0,07 & 0,11 & 0,11 & 0,41 & 0,32 & 0,59 \\
\hline $\mathrm{T}$ & 0,875 & 0,67 & 1 & 1 & 1 & 0,71 & 1 & 0,64 & 0,4 & 0,67 \\
\hline$S_{z}$ & 0,125 & 0,33 & 0 & 0 & 0 & 0,29 & 0 & 0,36 & 0,6 & 0,33 \\
\hline
\end{tabular}




\begin{tabular}{|c|c|c|c|c|c|c|c|c|c|c|}
\hline $\begin{array}{c}\text { Dane/ } \\
\text { losoby }\end{array}$ & $\mathbf{1}$ & $\mathbf{2}$ & $\mathbf{3}$ & $\mathbf{4}$ & $\mathbf{5}$ & $\mathbf{6}$ & $\mathbf{7}$ & $\mathbf{8}$ & $\mathbf{9}$ & $\mathbf{1 0}$ \\
\hline St & 0,68 & 0,95 & 0,98 & 0,95 & 0,93 & 0,89 & 0,89 & 0,59 & 0,68 & 0,41 \\
\hline W & 2,75 & 14,67 & 44 & 22 & 14,67 & 6,29 & 8,8 & 1,57 & 1,26 & 1,13 \\
\hline Odp. & 0,2 & 0,04 & 0,01 & 0,03 & 0,04 & 0,09 & 0,06 & 0,35 & 0,44 & 0,49 \\
\hline Wył. & 1.45 & 1,75 & 1,8 & 1,77 & 1,75 & 1,66 & 1,7 & 1,18 & 1,02 & 0,93 \\
\hline Ef. & 0,36 & 0,07 & 0,02 & 0,05 & 0,07 & 0,16 & 0,11 & 0,64 & 0,8 & 0,89 \\
\hline
\end{tabular}

Średnia dla wszystkich współczynników:

$\mathrm{K}=0,205, \mathrm{~T}=0,7965, \mathrm{Sz}=0,2035, \mathrm{St}=0,795$

$\mathrm{W}=11,615$, Odp.=0,175, Wył=1,501, Ef.=0,317

Podobnie jak w poprzednim przypadku osoby badane zamawiały mało jednostek, na ogół trafnie, przy czym kompletność zamówionych jednostek w stosunku do wszystkich jednostek relewantnych dla danego pytania była niska. Co ważne, można zaobserwować spore rozbieżności między wskaźnikami kompletności pomiędzy poszczególnymi osobami, od takich oscylujących w granicach 0, do wyników przekraczających 0,5, czyli przypadków odnalezienia $\mathrm{w}$ zbiorze ponad połowy dostępnej na dany temat informacji. Może to wskazywać na różny stopień zaangażowania i bardziej lub mnie wnikliwe zapoznanie się z treścią pomocy archiwalnej lub nieuniwersalnym jej językiem, niedostosowanym do wszystkich potencjalnych użytkowników.

\section{Urząd Gminy w Ciechocinie, 1973-1990}

Ramy chronologiczne omawianego zespołu przekraczają granicę 1981 roku, po której udostępnianie odbywa się jedynie na specjalne pozwolenie Dyrekcji APT. Ze 116 jednostek, które liczy zbiór, w wyniku selekcji pozostały 53, dlatego pominięto w tej sytuacji losowanie. Zespół posiada spis zdawczo-odbiorczy, w toku badania ustalono dla niego 2 tematy:

a) Zatrudnienie i kwalifikacje pracowników Urzędu Gminy

- Jednostki zawierające informacje do tematu: 21, 22, 39, 43, 55, 64, $66,68,69,70,72,73,74,76$

- Łączna liczba jednostek odpowiadających pytaniu: 14

Wartości stałe:

$\mathrm{X}=53$

$\mathrm{C}=14$ 


\begin{tabular}{|c|c|c|c|c|c|c|c|c|c|c|}
\hline $\begin{array}{l}\text { Dane/ } \\
\text { losoby }\end{array}$ & 1 & 2 & 3 & 4 & 5 & 6 & 7 & 8 & 9 & 10 \\
\hline A & 0 & 7 & 1 & 1 & 4 & 1 & 0 & 1 & 2 & 0 \\
\hline B & 2 & 11 & 1 & 2 & 10 & 4 & 2 & 1 & 4 & 2 \\
\hline \multicolumn{11}{|c|}{ Wskaźniki } \\
\hline $\mathrm{K}$ & 0 & 0,5 & 0,07 & 0,07 & 0,29 & 0,07 & 0 & 0,07 & 0,14 & 0 \\
\hline $\mathrm{T}$ & 0 & 0,64 & 1 & 0,5 & 0,4 & 0,25 & 0 & 1 & 0,5 & 0 \\
\hline$S_{z}$ & 1 & 0,36 & 0 & 0,5 & 0,6 & 0,75 & 1 & 0 & 0,5 & 1 \\
\hline St & 1 & 0,5 & 0,93 & 0,93 & 0,71 & 0,93 & 1 & 0,93 & 0,86 & 1 \\
\hline W & 7 & 1,27 & 14 & 7 & 1,4 & 3,5 & 7 & 14 & 3,5 & 7 \\
\hline Odp. & 0,04 & 0,21 & 0,02 & 0,04 & 0,19 & 0,08 & 0,04 & 0,02 & 0,08 & 0,04 \\
\hline Wył. & 3,64 & 3 & 3,71 & 3,64 & 3,07 & 3,5 & 3,64 & 3,71 & 3,5 & 3,64 \\
\hline Ef. & 0,14 & 0,79 & 0,07 & 0,14 & 0,71 & 0,29 & 0,14 & 0,07 & 0,29 & 0,14 \\
\hline
\end{tabular}

Średnia dla wszystkich współczynników:

$\mathrm{K}=0,121, \mathrm{~T}=0,429, \mathrm{Sz}=0,571, \mathrm{St}=0,879$

$\mathrm{W}=6,567$, Odp.=0,076, Wył=3,505, Ef.=0,278

b) Szkolnictwo na terenie gminy Ciechocin

- Jednostki zawierające informacje do tematu: 21, 22, 23, 25, 40, 58, 59, 61, 63, 64, 65, 67, 68, 69, 70, 71, 73, 74, 75, 76, 94

- Łączna liczba jednostek odpowiadających pytaniu: 21 Wartości stałe:

$\mathrm{X}=53$

$\mathrm{C}=22$

\begin{tabular}{|c|c|c|c|c|c|c|c|c|c|c|}
\hline $\begin{array}{l}\text { Dane/ } \\
\text { losoby }\end{array}$ & 1 & 2 & 3 & 4 & 5 & 6 & 7 & 8 & 9 & 10 \\
\hline A & 10 & 1 & 16 & 1 & 11 & 1 & 15 & 11 & 3 & 5 \\
\hline B & 25 & 5 & 19 & 1 & 15 & 2 & 18 & 14 & 4 & 7 \\
\hline \multicolumn{11}{|c|}{ Wskaźniki } \\
\hline $\mathrm{K}$ & 0,45 & 0,045 & 0,73 & 0,05 & 0,5 & 0,05 & 0,68 & 0,5 & 0,14 & 0,23 \\
\hline $\mathrm{T}$ & 0,4 & 0,2 & 0,84 & 1 & 0,73 & 0,5 & 0,83 & 0,79 & 0,75 & 0,71 \\
\hline$S z$ & 0,6 & 0,8 & 0,16 & 0 & 0,27 & 0,5 & 0,17 & 0,21 & 0,25 & 0,29 \\
\hline St & 0,55 & 0,955 & 0,27 & 0,95 & 0,5 & 0,95 & 0,32 & 0,5 & 0,86 & 0,77 \\
\hline
\end{tabular}




\begin{tabular}{|c|c|c|c|c|c|c|c|c|c|c|}
\hline $\begin{array}{c}\text { Danel } \\
\text { losoby }\end{array}$ & $\mathbf{1}$ & $\mathbf{2}$ & $\mathbf{3}$ & $\mathbf{4}$ & $\mathbf{5}$ & $\mathbf{6}$ & $\mathbf{7}$ & $\mathbf{8}$ & $\mathbf{9}$ & $\mathbf{1 0}$ \\
\hline W & 0,88 & 4,4 & 1,16 & 22 & 1,47 & 11 & 1,22 & 1,57 & 5,5 & 3,14 \\
\hline Odp. & 0,47 & 0,09 & 0,36 & 0,02 & 0,28 & 0,03 & 0,34 & 0,26 & 0,08 & 0,13 \\
\hline Wył. & 1,27 & 2,18 & 1,55 & 2,36 & 1,73 & 2,32 & 1,59 & 1,77 & 2,23 & 2,09 \\
\hline Ef. & 1,36 & 0,23 & 0,86 & 0,05 & 0,68 & 0,09 & 0,82 & 0,64 & 0,18 & 0,32 \\
\hline
\end{tabular}

Średnia dla wszystkich współczynników:

$\mathrm{K}=0,3375, \mathrm{~T}=0,675, \mathrm{Sz}=0,325, \mathrm{St}=0,6625$

$\mathrm{W}=5,234$, Odp. $=0,206, \mathrm{Wy}$ =1,909, Ef. $=0,523$

W przypadku tego zespołu nasuwają się wnioski bardzo podobne do tych dotyczących zespołu poprzedniego „Przedsiębiorstwo Nasiennictwa Ogrodniczego i Szkółkarstwa w Toruniu”, liczba wytypowanych, relewantnych jednostek przez użytkowników do tematu drugiego jest bardzo różna, niektóre wskaźniki są bardzo wysokie, jednak po przeliczeniu średniej jest on dużo niższy. Rozbieżności te mogą po raz kolejny być spowodowane nie daną pomocą, a sposobem poszukiwania informacji przez użytkowników. $\mathrm{O}$ „nieinformacyjności” spisu zdawczo-odbiorczego świadczą wyniki uzyskane do tematu pierwszego. Użytkownicy zamawiali mało jednostek, co czasem przekładało się w trafność na poziomie zerowym, a w ostatecznym przeliczeniu dało wskaźnik trafności niższy od 0,5 , czyli ponad połowa jednostek wytypowanych w czasie eksperymentu nie zawierała informacji dla określonego tematu. Treść pomocy dała fałszywe sygnały o zawartości, co rzutuje na niewłaściwe działanie systemu wyszukiwawczego.

\section{Akta stanu cywilnego parafii rzymskokatolickiej Ciechocin, 1670-1907}

Zespół jest zaopatrzony w inwentarz kartkowy, wylosowano 80 jednostek ze zbiorowości liczącej 89 pozycji. Zawiera on materiały napisane w języku polskim, rosyjskim i wyjątki w języku łacińskim, jednak inwentarz został w całości sporządzony po polsku. Badany materiał, zgodnie z przewidywaniami, okazał się jednorodny, zawierał akta metrykalne urodzeń, zgonów, małżeństw, czasem zapowiedzi. Spowodowało to duży problem w doborze tematów, co w końcu poskutkowało sformułowaniem tylko jednego. Materiały tego rodzaju są głównie przedmiotem badania genealogów, szukających w aktach konkretnych osób. W tym przypadku było to niemożliwe, zadaniem stało się 
sformułowanie ogólniejszego tematu, odnoszącego się do akt. Czynnikiem łączącym materiały było terytorium miejscowości, które na terenie parafii się znajdowały, i to w oparciu o jedną z nich temat został sporządzony.

a) Ruch naturalny ludności miejscowości Młyniec

- Jednostki zawierające informacje do tematu: wszystkie biorące udział w badaniu

- Łączna liczba jednostek odpowiadających pytaniu: 80 Wartości stałe:

$\mathrm{X}=80$

$\mathrm{C}=80$

\begin{tabular}{|c|c|c|c|c|c|c|c|c|c|c|}
\hline $\begin{array}{l}\text { Dane/ } \\
\text { losoby }\end{array}$ & 1 & 2 & 3 & 4 & 5 & 6 & 7 & 8 & 9 & 10 \\
\hline A & 72 & 74 & 80 & 80 & 80 & 80 & 80 & 80 & 77 & 80 \\
\hline B & 72 & 74 & 80 & 80 & 80 & 80 & 80 & 80 & 77 & 80 \\
\hline \multicolumn{11}{|c|}{ Wskaźniki } \\
\hline $\mathrm{K}$ & 0,9 & 0,925 & 1 & 1 & 1 & 1 & 1 & 1 & 0,96 & 1 \\
\hline $\mathrm{T}$ & 1 & 1 & 1 & 1 & 1 & 1 & 1 & 1 & 1 & 1 \\
\hline $\mathrm{Sz}$ & 0 & 0 & 0 & 0 & 0 & 0 & 0 & 0 & 0 & 0 \\
\hline St & 0,1 & 0,075 & 0 & 0 & 0 & 0 & 0 & 0 & 0,04 & 0 \\
\hline W & 1,11 & 1,08 & 1 & 1 & 1 & 1 & 1 & 1 & 1,04 & 1 \\
\hline Odp. & 0,9 & 0,925 & 1 & 1 & 1 & 1 & 1 & 1 & 0,96 & 1 \\
\hline Wył. & 0,1 & 0,075 & 0 & 0 & 0 & 0 & 0 & 0 & 0,04 & 0 \\
\hline Ef. & 0,9 & 0,925 & 1 & 1 & 1 & 1 & 1 & 1 & 0,96 & 1 \\
\hline
\end{tabular}

Średnia dla wszystkich współczynników:

$\mathrm{K}=0,9785, \mathrm{~T}=1, \mathrm{Sz}=0, \mathrm{St}=0,0215$

$\mathrm{W}=1,023$, Odp.=0,9785, Wył=0,0215, Ef.=0,9785

Wartość $C$ w tym badaniu wynosi 80, czyli wszystkie wylosowane jednostki zawierają informacje do danego tematu. Jest to sytuacja bardzo specyficzna, niezamierzona przez badacza, ale jednak ciekawa i pozwalająca sprawdzić, jak współczynniki w takiej sytuacji reagują. Jak okazało się później, inwentarz nie zawierał indeksu geograficznego, dlatego też użytkownicy nie mogli w żaden sposób, bez wglądu do danych ksiąg, ocenić, gdzie znajdą informacje o miejscowości Młyniec. Większość badanych zareagowała na 


\section{Monika CoŁbecka}

to $\mathrm{w}$ ten sposób, że zamówiła wszystkie akta, niektórzy odrzucali po kilka jednostek, z pewnością, ich zdaniem, ewidentnie niezawierających pożądanych informacji, czy też zawierających informację powtarzalną. Kompletność w tym przypadku jest bliska wartości 1, nie można jednak tego tłumaczyć dobrze działającym elementem systemu, jakim jest język pomocy pochodnej; osoby zamawiały jednostki raczej dlatego, że nie wiedziały, gdzie jest, a gdzie na pewno nie ma informacji. Mogłoby się zdarzyć, że przy $100 \%$ relewantności danego zbioru dla danego pytania system nie wyszuka żadnej jednostki. Interpretacja wskaźników szumu oraz trafności w takim przypadku nie ma większego sensu, tu zawsze wartość wynosi 1 (dla trafności), gdyż nie ma w zbiorze materiałów niezawierających informacji relewantnych. Jedynym wnioskiem co do trafności i szumu jest to, że obliczanie tych wskaźników dla zespołów, gdzie na dany temat odpowiada duży procent jednostek archiwalnych, jest bezzasadny. Już na początku wiadomo, że mało materiałów jest nierelewantnych, a wskazanie tych źle opisanych w pomocy, „udających” informację dla tematu, jest trudna.

\section{Bydgoski Okręgowy Związek Piłki Ręcznej w Grudziądzu, 1956-1973} Zbiorowość generalna - tak językiem statystyków nazwiemy zespół archiwalny - w tym przypadku zawiera mniej jednostek od liczby, która powinna zostać wylosowana, dlatego czynność ta w przypadku „Bydgoskiego Okręgowego Związku Piłki Ręcznej w Grudziądzu” została pominięta. Badaniu podlega cały zespół, czyli 64 jednostki archiwalne, który zaopatrzony jest w inwentarz archiwalny, książkowy. Ustalone dwa tematy do zespołu różnią się swoim zakresem, drugi jest zdecydowanie szerszy, odpowiada mu dużo więcej jednostek, dotyczy każdego rodzaju rozgrywek, odbywających się na wytypowanym terytorium w określonym czasie, temat tak ogólny został podyktowany przewidywaną, raczej nikłą znajomością dziedziny, reprezentowanej przez omawiany zespół, wśród osób poddanych eksperymentowi.

a) Organizacja Okręgowych Związków Piłki Ręcznej na przykładzie Bydgoskiego Okręgowego Związku Piłki Ręcznej

- Jednostki zawierające informacje do tematu: 1, 2, 15, 17, 18, 19, 21, $22,23,28,37$

- Łączna liczba jednostek odpowiadających pytaniu: 11

Wartości stałe:

$\mathrm{X}=64$

$\mathrm{C}=11$ 


\begin{tabular}{|c|c|c|c|c|c|c|c|c|c|c|}
\hline $\begin{array}{l}\text { Dane/ } \\
\text { losoby }\end{array}$ & 1 & 2 & 3 & 4 & 5 & 6 & 7 & 8 & 9 & 10 \\
\hline A & 7 & 10 & 7 & 6 & 8 & 10 & 9 & 3 & 6 & 2 \\
\hline B & 12 & 30 & 11 & 7 & 17 & 37 & 14 & 8 & 8 & 3 \\
\hline \multicolumn{11}{|c|}{ Wskaźniki } \\
\hline $\mathrm{K}$ & 0,64 & 0,91 & 0,64 & 0,545 & 0,73 & 0,91 & 0,82 & 0,27 & 0,55 & 0,18 \\
\hline $\mathrm{T}$ & 0,58 & 0,33 & 0,64 & 0,86 & 0,47 & 0,27 & 0,64 & 0,375 & 0,75 & 0,67 \\
\hline $\mathrm{Sz}$ & 0,42 & 0,67 & 0,36 & 0,14 & 0,53 & 0,73 & 0,36 & 0,625 & 0,25 & 0,33 \\
\hline St & 0,36 & 0,09 & 0,36 & 0,454 & 0,27 & 0,09 & 0,18 & 0,73 & 0,45 & 0,82 \\
\hline W & 0,92 & 0,37 & 1 & 1,57 & 0,65 & 0,29 & 0,79 & 1,38 & 1,38 & 3,67 \\
\hline Odp. & 0,19 & 0,47 & 0,17 & 0,11 & 0,27 & 0,58 & 0,22 & 0,13 & 0,13 & 0,05 \\
\hline Wył. & 4,73 & 3,09 & 4,82 & 5,18 & 4,27 & 2,45 & 4,55 & 5,09 & 5,09 & 5,55 \\
\hline Ef. & 1,09 & 2,73 & 1 & 0,64 & 1,55 & 3,36 & 1,27 & 0,73 & 0,73 & 0,27 \\
\hline
\end{tabular}

Średnia dla wszystkich współczynników:

$\mathrm{K}=0,6195, \mathrm{~T}=0,5585, \mathrm{Sz}=0,4415, \mathrm{St}=0,3804$

$\mathrm{W}=1,202$, Odp.=0,232, Wył=4,482, Ef. $=1,337$

b) Rozgrywki piłki ręcznej w województwie bydgoskim w latach 1957$-1975$

- Jednostki zawierające informacje do tematu: 1, 2, 3, 4, 5, 6, 7, 8, 9, $10,11,12,13,14,16,17,18,19,24,28,40,41,42,43,44,45,46$, $47,48,49,50,51,52,53,54,55,56,57,59,61,62,64$

- Łączna liczba jednostek odpowiadających pytaniu: 42 Wartości stałe:

$\mathrm{X}=64$

$\mathrm{C}=42$

\begin{tabular}{|c|c|c|c|c|c|c|c|c|c|c|}
\hline $\begin{array}{l}\text { Dane/ } \\
\text { losoby }\end{array}$ & 1 & 2 & 3 & 4 & 5 & 6 & 7 & 8 & 9 & 10 \\
\hline A & 36 & 20 & 20 & 22 & 21 & 22 & 18 & 8 & 22 & 23 \\
\hline B & 38 & 23 & 25 & 25 & 27 & 30 & 20 & 8 & 26 & 28 \\
\hline \multicolumn{11}{|c|}{ Wskaźniki } \\
\hline $\mathrm{K}$ & 0,86 & 0,48 & 0,48 & 0,52 & 0,5 & 0,52 & 0,43 & 0,19 & 0,52 & 0,55 \\
\hline $\mathrm{T}$ & 0,95 & 0,87 & 0,8 & 0,88 & 0,78 & 0,73 & 0,9 & 1 & 0,85 & 0,82 \\
\hline $\mathrm{Sz}$ & 0,05 & 0,13 & 0,2 & 0,12 & 0,22 & 0,27 & 0,1 & 0 & 0,15 & 0,18 \\
\hline
\end{tabular}




\begin{tabular}{|c|c|c|c|c|c|c|c|c|c|c|}
\hline $\begin{array}{c}\text { Dane/ } \\
\text { losoby }\end{array}$ & $\mathbf{1}$ & $\mathbf{2}$ & $\mathbf{3}$ & $\mathbf{4}$ & $\mathbf{5}$ & $\mathbf{6}$ & $\mathbf{7}$ & $\mathbf{8}$ & $\mathbf{9}$ & $\mathbf{1 0}$ \\
\hline St & 0,14 & 0,52 & 0,52 & 0,48 & 0,5 & 0,48 & 0,57 & 0,81 & 0,48 & 0,45 \\
\hline W & 1,11 & 1,83 & 1,68 & 1,68 & 1,56 & 1,4 & 2,1 & 5,25 & 1,61 & 1,5 \\
\hline Odp. & 0,59 & 0,36 & 0,39 & 0,39 & 0,42 & 0,47 & 0,31 & 0,13 & 0,41 & 0,44 \\
\hline Wył. & 0,62 & 0,98 & 0,93 & 0,93 & 0,88 & 0,81 & 1,05 & 1,33 & 0,9 & 0,86 \\
\hline Ef. & 0,9 & 0,55 & 0,3 & 0,6 & 0,64 & 0,71 & 0,48 & 0,19 & 0,62 & 0,67 \\
\hline
\end{tabular}

Średnia dla wszystkich współczynników:

$\mathrm{K}=0,505, \mathrm{~T}=0,858, \mathrm{Sz}=0,142, \mathrm{St}=0,495$

$\mathrm{W}=1,972$, Odp. $=0,391, \mathrm{Wyl}=0,929, \mathrm{Ef} .=0,596$

Wskaźniki kompletności dla zespołu są dużo wyższe niż poprzednio, w obu przypadkach użytkownicy wytypowali ponad połowę relewantnych materiałów. Rzeczą równie interesującą jest pierwszy w przeprowadzonym badaniu przypadek, gdy wskaźnik trafności był niższy od wskaźnika kompletności. Stało się tak dla tematu pierwszego, do którego jedynie 1/6 jednostek można określić jako relewantną informacyjnie. Użytkownicy typowali w większości przypadków wiele jednostek, z których część nie odpowiadała na zapytanie informacyjne. Wniosek może być taki, że opracowany dla zespołu inwentarz charakteryzuje się opisem poszczególnych pozycji na zbyt ogólnym poziomie, wskazuje na informacje zawarte w określonych materiałach, jak i na takie, których tam nie ma.

\section{Kościół parafialny w Kaszczorku i filialny w Złotorii, 1779-1934}

Zespół jest w całości opracowany oraz zaopatrzony w inwentarz książkowy. Zawiera 164 jednostki w języku niemieckim lub łacińskim, w języku niemieckim sporządzona została pomoc archiwalna (zawiera mały procent języka polskiego) i, co już wcześniej było uzasadnione, stanowiło to powód do ograniczenia liczby osób, biorących udział w eksperymencie, do pięciu. Oto sformułowane tematy:

a) Zarządzanie majątkiem parafialnym w kościele w Kaszczorku

- Jednostki zawierające informacje do tematu: 4, 5, 20, 21, 26, 29, 35, $39,40,42,44,45,49,52,53,54,55,57,59,63,64,67,69,70,73$, $75,77,78,79,84,86,88,89,93,94,95,99,105,106,108,112$, $118,121,123,131,135,136$ 
- Łączna liczba jednostek odpowiadających pytaniu: 47 Wartości stałe:

C-47

X- 80

\begin{tabular}{|c|c|c|c|c|c|c|}
\hline Dane/osoby & $\mathbf{1}$ & $\mathbf{2}$ & $\mathbf{3}$ & $\mathbf{4}$ & $\mathbf{5}$ \\
\hline A & 24 & 37 & 30 & 40 & 36 \\
\hline B & 28 & 55 & 41 & 48 & 43 \\
\hline Wskaźniki & & & & \\
\hline K & 0,51 & 0,79 & 0,64 & 0,85 & 0,766 \\
\hline T & 0,86 & 0,67 & 0,73 & 0,83 & 0,84 \\
\hline Sz & 0,14 & 0,33 & 0,27 & 0,17 & 0,16 \\
\hline St & 0,49 & 0,21 & 0,36 & 0,15 & 0,23 \\
\hline W & 1,68 & 0,85 & 1,15 & 0,98 & 1,09 \\
\hline Odp. & 0,35 & 0,69 & 0,51 & 0,6 & 0,54 \\
\hline Wył. & 1,11 & 0,53 & 0,83 & 0,68 & 0,79 \\
\hline Ef. & 0,6 & 1,17 & 0,87 & 1,02 & 0,91 \\
\hline
\end{tabular}

Średnia dla wszystkich współczynników:

$\mathrm{K}=0,7112, \mathrm{~T}=0,786, \mathrm{Sz}=0,214, \mathrm{St}=0,288$

$\mathrm{W}=1,15$, Odp.=0,538, Wył=0,788, Ef.=0,914

b) Historia kościoła w Złotorii

- Jednostki zawierające informacje do tematu: 21, 143, 146, 148, 149, $155,156,159$

- Łączna liczba jednostek odpowiadających pytaniu: 9

Wartości stałe:

$\mathrm{X}=80$

$\mathrm{C}=9$

\begin{tabular}{|c|c|c|c|c|c|}
\hline Dane/osoby & $\mathbf{1}$ & $\mathbf{2}$ & $\mathbf{3}$ & $\mathbf{4}$ & $\mathbf{5}$ \\
\hline A & 7 & 6 & 3 & 2 & 7 \\
\hline B & 10 & 7 & 3 & 2 & 8 \\
\hline Wskaźniki & \multicolumn{5}{|l}{} \\
\hline K & 0,78 & 0,67 & 0,33 & 0,22 & 0,78 \\
\hline
\end{tabular}




\begin{tabular}{|c|l|l|l|l|l|}
\hline Dane/osoby & $\mathbf{1}$ & $\mathbf{2}$ & $\mathbf{3}$ & $\mathbf{4}$ & $\mathbf{5}$ \\
\hline $\mathrm{T}$ & 0,7 & 0,86 & 1 & 1 & 0,875 \\
\hline $\mathrm{Sz}$ & 0,3 & 0,14 & 0 & 0 & 0,125 \\
\hline $\mathrm{St}$ & 0,22 & 0,33 & 0,67 & 0,78 & 0,22 \\
\hline $\mathrm{W}$ & 0,9 & 1,29 & 3 & 8,67 & 1,125 \\
\hline Odp. & 0,125 & 0,09 & 0,03 & 0,025 & 0,1 \\
\hline Wył. & 7,78 & 8,11 & 8,56 & 8,67 & 8 \\
\hline Ef. & 1,11 & 0,78 & 0,33 & 0,22 & 0,89 \\
\hline
\end{tabular}

$$
\begin{aligned}
& \text { Średnia dla wszystkich współczynników: } \\
& \mathrm{K}=0,556, \mathrm{~T}=0,887, \mathrm{Sz}=0,113, \mathrm{St}=0,444 \\
& \mathrm{~W}=2,997, \mathrm{Odp} .=0,074, \mathrm{Wy}=8,224, \mathrm{Ef} .=0,666
\end{aligned}
$$

Wskaźniki obliczone dla tego zespołu są wysokie, szczególnie w przypadku tematu pierwszego, który miał szerszy zakres i więcej jednostek relewantnych spośród części poddanej badaniu. Trafność wskazuje, że osoby w zasadzie nie myliły się w swoim typowaniu. Możemy zauważyć w tym przypadku to, o czym pisał już Ryszewski ${ }^{52}$, tj. o zależności kompletności od trafności, im większa wartość jednej, tym mniejsza drugiej. Stosunek wskaźników trzeba dla każdego przypadku rozstrzygać indywidualnie.

\section{Urząd Stanu Cywilnego Szembruczek, 1874-1905}

Zespół według bazy danych Sezam liczy 139 jednostek archiwalnych oraz zaopatrzony jest w inwentarz kartkowy. Niestety jest to informacja błędna, ponieważ tylko 42 jednostki są opracowane i posiadają wspomniany inwentarz, reszta jednostek, które sukcesywnie są przejmowane przez Archiwum Państwowe w Toruniu, udostępniana jest na podstawie spisów zdawczo-odbiorczych, dodatkowo obejmujących Urząd Stanu Cywilnego w Rogóźnie. Dodatkową pomyłką w ewidencji jest liczba jednostek w zespole, gdyż po zsumowaniu przez badacza tych w inwentarzu i spisie, wynik wynosił 104 . I to właśnie spośród tej liczby losowano 80 jednostek. Ponadto spośród wylosowanego zbioru cztery jednostki nie zostały odnalezione, dlatego też ograniczono badanie do liczby 76 . Nie można jednak zapomnieć, że brak tych jednostek wpływa ujemnie na ocenę działania systemu informacji archiwal-

52 B. Ryszewski,dz. cyt., s. 141-142. 
nej. Ze względu na same akta, jak i inwentarz spisany w języku niemieckim, badaniu poddano tylko pięć osób. Zespół ten tworzą materiały jednorodne, czyli księgi metrykalne, i dlatego powtórzono w tym przypadku schemat formułowania tematu do „Akt stanu cywilnego parafii rzymskokatolickiej Ciechocin”.

a) Ruch naturalny ludności w miejscowości Bukowiec w XIX wieku.

- Jednostki zawierające informacje do tematu: 4, 5, 6, 11, 12, 13, 14, $15,16,18,19,20,21,22,24,25,27,29,36,39,45,50,56,57,61$, $62,63,65,67,71,72$

- Łączna liczba jednostek odpowiadających pytaniu: 31 Wartości stałe:

$\mathrm{X}=76$

$\mathrm{C}=31$

\begin{tabular}{|c|l|l|l|l|l|}
\hline Dane/osoby & $\mathbf{1}$ & $\mathbf{2}$ & $\mathbf{3}$ & $\mathbf{4}$ & $\mathbf{5}$ \\
\hline $\mathrm{A}$ & 31 & 31 & 31 & 27 & 11 \\
\hline B & 76 & 76 & 54 & 37 & 16 \\
\hline Wskaźniki & & & & & \\
\hline K & 1 & 1 & 1 & 0,87 & 0,35 \\
\hline T & 0,41 & 0,41 & 0,57 & 0,73 & 0,69 \\
\hline Sz & 0,59 & 0,59 & 0,43 & 0,27 & 0,31 \\
\hline St & 0 & 0 & 0 & 0,13 & 0,65 \\
\hline W & 0,41 & 0,41 & 0,57 & 0,84 & 1,94 \\
\hline Odp. & 1 & 1 & 0,71 & 0,49 & 0,21 \\
\hline Wył. & 0 & 0 & 0,71 & 1,26 & 1,94 \\
\hline Ef. & 2,45 & 2,45 & 1,74 & 1,19 & 0,52 \\
\hline
\end{tabular}

Średnia dla wszystkich współczynników:

$\mathrm{K}=0,844, \mathrm{~T}=0,562, \mathrm{Sz}=0,438, \mathrm{St}=0,156$

$\mathrm{W}=0,834$, Odp.=0,682, Wył=0,782, Ef. $=1,67$

$\mathrm{Na}$ ogół typowano równą liczbę jednostek, odpowiadających tematowi, a w dwóch przypadkach osoby stwierdziły, że wszystkie akta odnoszą się do tematu. Badanie tego zespołu przypomina przypadek „Akt stanu cywilnego parafii rzymskokatolickiej Ciechocin”, jednak są tu istotne różnice. Po pierwsze nie wszystkie jednostki zawierają informację o ruchu naturalnym ludności 
w miejscowości Bukowiec; chociaż i w tym przypadku inwentarz czy też spisy nie zawierają indeksu geograficznego, to użytkownicy mogli zawęzić liczbę wytypowanych jednostek ze względu na ramy czasowe, jakie wyznaczał temat. Dlatego też przypadki, gdy osoby wskazywały wszystkie jednostki tematu, może oznaczać jego niezrozumienie. Elementem wpływającym na złe działanie systemu, oprócz pomocy pochodnych, są też użytkownicy. W badaniu tym potwierdziła się teza wyprowadzona dla poprzedniego zespołu - wysoki wskaźnik kompletności wpływa na zmniejszenie trafności.

\section{WNIOSKI}

Badając podsystem wyszukiwania - jeden z elementów składających się na system informacji archiwalnej, nie można pominąć opisu i oceny: zbioru źródeł pierwotnych, opracowanie tego zbioru, zbioru informacji pochodnych, użytkowników informacji archiwalnej i udostępniania, a także wzajemnych relacji między nimi. Ocenę systemu wyszukiwawczego musi poprzedzić zbadanie jego efektywności informacyjnej, na co pozwalają obliczone wcześniej wskaźniki. Oczywiście same wyniki działań matematycznych nie są miarodajnym czynnikiem oceny, analiza ilościowa stanowi tylko podstawę do analizy jakościowej, czyli oceny systemu informacji archiwalnej.

Jedynie cztery wskaźniki, użyte w dziedzinie archiwalnej, dają wyniki, które archiwiści mogą interpretować, są to: kompletność, trafność, szum i strata, w praktyce można skupiać się na obliczaniu jedynie dwóch pierwszych współczynników, gdyż znając np. wartość wskaźnika kompletności i po odjęciu go od 1, otrzymujemy wartość wskaźnika strat, to samo dzieje się z drugą parą. Kompletność daje nam wiedzę, ile relewantnych jednostek odszukaliśmy, a wskaźnik strat, ile ich nie wytypowaliśmy. Uzasadnienie co do zbędności używania wskaźników: wyszukiwania, efektywności języka informacyjnego, odpowiedzi i wyłączenia zostało już przedstawione wcześniej; ujmując rzecz ogólnie, głównym celem obliczania wartości jest ocena, na ile system jest w stanie wydać poprawne odpowiedzi na zapytania informacyjne, a one danych do takiej oceny nie dostarczają.

Badanie to pozwoliło wskazać błędy w systemie, w poszczególnych jego elementach, gdyż w toku badania, a także dzięki obliczeniu wskaźników, zdobyto do tego niezbędne informacje. W toku analizowania treści jednostek archiwalnych ocenie podlegał zbiór źródeł pierwotnych oraz obsługa archi- 
wum. Dużym problemem okazało się w tym wypadku uporządkowanie zasobu, gdy na podstawie pomocy archiwalnych zamawiano jednostki i okazywało się, że ich nie ma. Czy nie były one przechowywane w magazynie, czy zostały źle opracowane? Nie ma odpowiedzi na to pytanie.

Analizując dane, dostarczone w trakcie eksperymentu, czyli obliczając wskaźniki na podstawie odpowiedzi, udzielonych przez dziesięć lub pięć osób (w dwóch przypadkach), można wyciągać wnioski dotyczące opracowania danej pomocy archiwalnej, a także ocenić użytkowników. W jednym przypadku osoby nie zrozumiały tematu i stąd złe typowanie jednostek. Jeśli wyniki pomiędzy poszczególnymi osobami bardzo się różniły, czyli na przykład jedna osoba wytypowała do zamówienia kilkanaście jednostek, a kolejna tylko kilka, oznaczało to nierówny stopień zaangażowania w przeprowadzone badanie i wtedy możemy mówić, że podsystem użytkowników działa wadliwie. W przypadku, gdy użytkownicy zamawiają trafnie jednostki, a jednak wskaźnik kompletności jest niski, wina leży po stronie pomocy archiwalnej, gdyż trafność wskazuje, że użytkownicy w swych ocenach nie mylą się, jedynie system pomocy archiwalnych nie daje im pełnej informacji o zawartości, przez co nie mogą typować kompletnie.

Przechodząc do porównywania wyników między poszczególnymi zespołami, bardzo wyraźna jest różnica między wartościami wskaźników kompletności w przypadku zespołów opracowanych, zaopatrzonych w inwentarze, a tych udostępnianych na podstawie spisów zdawczo-odbiorczych. Wskaźnik kompletności dla zespołów z inwentarzami waha się między wartością 0,322 a 0,9785, ten sam wskaźnik dla zespołów ze spisami zdawczo-odbiorczymi wynosi 0,098-0,3375. Analizując ten wynik, krystalizuje się nam główny wniosek, jaki przyniosło badanie systemu informacji archiwalnej, odnoszący się do elementu, jakim jest zbiór źródeł pochodnych i język informacyjny użyty do ich sporządzenia. Wprowadzone w roku 2002 zasady uproszczonego opracowania zasobu archiwalnego ${ }^{53}$ znacząco obniżyły efektywność wyszukiwania. Mimo podniesienia procentowego udziału zespołów udostępnianych w skali całego zasobu spadła jego przydatność informacyjna. Użytkownikowi niepotrzebne są zespoły, w których i tak informacji przydatnej nie znajdzie.

53 Zarządzenie nr 20 Naczelnego Dyrektora Archiwów Państwowych z dnia 10 grudnia 2002 r. w sprawie wprowadzenia wskazówek metodycznych dotyczących uproszczonego opracowania zasobu archiwalnego przechowywanego w archiwach państwowych. [on-line] [Dostęp 5 lipca 2011 r.] Dostępny w World Wide Web: http://www. archiwa.gov.pl/images/stories/file/pdf/dec_20_2002.pdf. 
Konkludując, zespół źle opracowany lub w ogóle nieopracowany prawdopodobnie wyklucza daną informację z przyszłego wykorzystania.

Wskaźnik trafności ma tak naprawdę znaczenie uzupełniające dla wskaźnika kompletności. O ile przy obliczaniu kompletności możemy dokładnie oznaczyć, które jednostki, choć relewantne dla danego pytania, są źle opisane w pomocy archiwalnej, to wskaźnik trafności daje nam tylko przypuszczalną liczbę jednostek, opisanych w ten sposób, że odpowiadają w systemie fałszywą relewantnością. Badania z wykorzystaniem wskaźników efektywności informacyjnej mogą mieć sens, jeśli byłyby prowadzone regularnie lub gdyby poddawać im zespoły w trakcie opracowywania.

Celem niniejszego badania było sprawdzenie, czy możliwe jest wprowadzenie metod badawczych, które dotąd w archiwistyce nie były używane lub używane były sporadycznie. Praktyka pokazała, że zastosowanie do badania informacji archiwalnej metod, które raczej wydają się w połączeniu z archiwum egzotyczne, jest możliwe. Aczkolwiek wprowadzenie wzorów matematycznych i statystyki, próba „zmierzenia” informacji zawartej w aktach nie jest wolna od problemów i to czasem bardzo dużych.

Przeprowadzone badanie jest nowatorskie, dlatego nie można stwierdzić, że jest wolne od błędów i wymaga ulepszeń. Jego największą wartością jest przetarcie szlaków dla kolejnych badaczy, zajmujących się tą problematyką, mogłoby to prowadzić do rzeczywistego ulepszenia systemu informacji archiwalnej, tym bardziej, że przyjęte metody badania pozwalają ocenić wszystkie elementy interesującego nas systemu: zasób archiwum, pomoce ewidencyjno-informacyjne, użytkowników, obsługę archiwum i relacje zachodzące między nimi.

Przyjęty model badania niewątpliwie wymaga ulepszenia, polegającego przede wszystkim na jeszcze większym dostosowaniu go do archiwistyki. Chociaż badanie przyniosło wnioski, wskazujące błędy w procesie informacyjnym systemu, rozszerzenie badania, przynajmniej na poprzedni system informacyjny Archiwum Państwowego w Toruniu, dałoby wnikliwszą ocenę pomocy archiwalnych, a to za sprawą ich porównania. Kolejnym elementem, wymagającym modyfikacji, jest zakres losowania próby do badania; metoda reprezentacyjna w stosunku do zespołów archiwalnych jest jak najbardziej wskazana, jednak losowanie określonej liczby jednostek w poszczególnych zespołach nie wydaje się konieczną, a nawet potrzebną czynnością. Cenniejsze może okazać się badanie całych zespołów, stanowiących nierozerwalną całość. Tylko zespół postrzegany jako wszystkie wchodzące w jego skład jed- 
nostki archiwalne, stanowi źródło pełnej informacji, decyduje o jego odrębności w stosunku do innych zespołów.

Losowanie zespołów również może ulec modyfikacji, bogatsza o doświadczenia uważam, że dla lepszych wniosków w badaniu powinny brać udział zespoły „popularniejsze” wśród użytkowników, często zamawiane i udostępniane. Dlatego przed przystąpieniem do losowania można przeprowadzić selekcję zespołów i zająć się w pierwszej kolejności często wykorzystywanymi, a ulepszenie informacji o nich przyniosłoby natychmiastową poprawę funkcjonowania systemu. Ponadto podobnie można postąpić w kwestii wyboru tematów, odnoszących się do wybranych zespołów, do których użytkownicy na podstawie pomocy archiwalnych typują jednostki, zawierające pożądaną informację, a co następnie przeliczane jest na wskaźniki efektywności informacyjnej systemu. Zasadniczym celem ulepszenia systemu informacji archiwalnej jest podniesienie satysfakcji użytkowników z obsługi archiwalnej, więc poznanie tendencji w badaniach, prowadzonych na podstawie zasobu archiwalnego, pomogłoby wyznaczyć tematy szczególnie popularne wśród użytkowników.

Chociaż przeprowadzone badanie wymaga w przyszłości dużych modyfikacji, potwierdza możliwość wykorzystania ich w praktyce. Jest to tym ważniejsze, że do tej pory metody te nie wychodziły poza ramy opisu teoretycznego. Praca ta może stanowić zaczątek badania systemu informacji archiwalnej, opierającej się na metodzie matematycznej, przy pomocy dwóch wskaźników efektywności informacyjnej: kompletności i trafności.

Bibliografia

Burzyński A., Elementy statystyki dla historyków: materiaty do ćwiczeń, wyktadów i metodyki prac badawczych, t. 1, Kraków 1980.

Chorążyczewski W., Akta i księgi wpisów w Archiwum Państwowym w Toruniu. Systemy informacyjne, [w:] Kancelarie okresu księgi wpisów w Prusach Królewskich. Materiały sesji odbytej 20-21 listopada 1992 roku w Archiwum Państwowym w Toruniu, red. A. Tomczak, Warszawa 1994.

Chorążyczewski W., Nowożytny dokument królewski. Możliwości badawcze, [w:] Polska kancelaria królewska czasów nowożytnych między wtadzą a spoteczeństwem, pod red. W. Chorążyczewskiego i W. Krawczuka, Toruń 2003.

Czarnecki M., Metodologiczne podstawy naukowego rozwoju studentów, Sosnowiec 2009.

Gładys Z., Pogorzelski W., Elementy analizy systemowej, Płock 2002. 


\section{Monika CoŁbecka}

Gołembiowski M., System i informacji archiwalnej, Warszawa-Łódź 1985.

Kieżun W., Podstawy organizacji i zarzadzania, Warszawa 1977.

Kisilowska M., Modelowanie rozlegtych systemów informacyjnych. Zdrowie i kultura, Warszawa 2009.

Maszke A. W., Metodologiczne podstawy badań pedagogicznych, Rzeszów 2004.

Meadow Ch., Analiza systemów informacyjnych, Warszawa 1972.

Miszczak W., Ostasiewicz W., Wawrzynek J., Projektowanie próby z elementami planowania eksperymentów, Wrocław 2008.

Mróz M., Sirko S., Elementy statystyki w badaniach naukowych, [w:] Metody i narzędzia badawcze oraz elementy statystyki stosowane $w$ pracach magisterskich $i$ doktorskich, red. M. Cieślarczyk, Warszawa 2003.

Piter J., Zarys Metodologii naukowej, Warszawa 1975.

Pomykała J. M., Pomykała J. A., Systemy informacyjne. Modelowanie i wybrane techniki kryptograficzne, Warszawa 1999.

Rosa A., Archiwa między historia i pamięcia. Antropologizowanie archiwistyki, [w:] Archiwa - Kancelarie - Zbiory, t. 2, red. W. Chorążyczewski, R. Degen, K. Syta, Toruń 2008.

Ryszewski B., Problemy i metody badawcze archiwistyki, Toruń 1985.

Schoderback P. P., Schoderback C. G., Kefalas A. G., Management systems, Homewood 1990.

Zasępa R., Metoda reprezentacyjna, Warszawa 1972.

\section{S u m m a ry}

\section{Case study of the State Archives in Torun as an archival information system}

The purpose of this text is to show the methods of researching the archive information system (the search system and share system) with use of mathematical methods. The research consisted of choosing a representative number of fonds and units within them, collecting (without using finding aids) pieces of information they contain, and then conducting an experiment on a group of people, whose task was to provide estimates as to which of the fonds a given piece of information was located in, with the use if finding aids.

The following research methods were used for this study: survey sampling, experiment, mathematical methods.

The figures obtained with them have been used for calculating the information effectiveness ratio, which is the core of the system analysis of the State Archives in Torun. The main body of the article is an attempt to find out if calculating the information effectiveness ratios can supply us with data that is able to effectively influence the assessment of the system. 
The study allowed us to examine to a greater or lesser extent all the elements of the archival information system, and to draw conclusions, that indicate the elements of each of the fonds, that need to be modified in order to improve on the way the system operates.

Calculating the ratios has allowed us to gauge the usefulness of a given finding aid, and draw a conclusion that the introduction of the guidelines for the simplified description of archival holdings have essentially influenced on the of information searching effectiveness. 